\title{
ASSESSING MANDATED CREDIT PROGRAMS: CASE STUDY OF THE MAGNA CARTA IN THE PHILIPPINES
}

Niny Khor, Ryan Jacildo, and Ruth Tacneng

NO. 463

November 2015
ADB ECONOMICS WORKING PAPER SERIES 
ADB Economics Working Paper Series

\section{Assessing Mandated Credit Programs: Case Study of the Magna Carta in the Philippines}

Niny Khor, Ryan Jacildo, and Ruth Tacneng

No. 463 | November 2015
Niny Khor (nkhor@adb.org) is Economist at the Asian Development Bank's (ADB) PRC Resident Mission. Ruth Tacneng (rtacneng@porto.ucp.pt) is Postdoctoral Research Fellow at the CEGE and School of Economics and Management, Universidade Catolica Portuguesa. Ryan Jacildo (ryan.jacildo@barcelonagse.eu)was a Consultant at the Economic Research and Regional Cooperation Department, ADB. 
Asian Development Bank

6 ADB Avenue, Mandaluyong City

1550 Metro Manila, Philippines

www.adb.org

(C) 2015 by Asian Development Bank

November 2015

ISSN 2313-6537 (Print), 2313-6545 (e-ISSN)

Publication Stock No. WPS157764-2

The views expressed in this paper are those of the authors and do not necessarily reflect the views and policies of the Asian Development Bank (ADB) or its Board of Governors or the governments they represent.

ADB does not guarantee the accuracy of the data included in this publication and accepts no responsibility for any consequence of their use.

By making any designation of or reference to a particular territory or geographic area, or by using the term "country" in this document, $A D B$ does not intend to make any judgments as to the legal or other status of any territory or area.

Notes:

1. In this publication, “\$” refers to US dollars.

2. ADB recognizes "China" as the People's Republic of China.

The ADB Economics Working Paper Series is a forum for stimulating discussion and eliciting feedback on ongoing and recently completed research and policy studies undertaken by the Asian Development Bank (ADB) staff, consultants, or resource persons. The series deals with key economic and development problems, particularly those facing the Asia and Pacific region; as well as conceptual, analytical, or methodological issues relating to project/program economic analysis, and statistical data and measurement. The series aims to enhance the knowledge on Asia's development and policy challenges; strengthen analytical rigor and quality of ADB's country partnership strategies, and its subregional and country operations; and improve the quality and availability of statistical data and development indicators for monitoring development effectiveness.

The ADB Economics Working Paper Series is a quick-disseminating, informal publication whose titles could subsequently be revised for publication as articles in professional journals or chapters in books. The series is maintained by the Economic Research and Regional Cooperation Department. 


\section{CONTENTS}

TABLES AND FIGURES IV iv

ABSTRACT $v$ V

$\begin{array}{ll}\text { I. INTRODUCTION } & 1\end{array}$

II. FINANCING MICRO, SMALL, AND MEDIUM ENTERPRISES IN THE PHILIPPINES 2
A. Definitions 2
B. Sources of Credit 4
C. The Micro, Small, and Medium Enterprise Magna Carta 5
D. Other Initiatives to Encourage Lending to Micro, Small, and Medium Enterprises 7
E. The Structure of the Banking Industry in the Philippines 8

III. COMPLIANCE TO THE MICRO, SMALL, AND MEDIUM ENTERPRISE MAGNA CARTA

A. Direct Compliance 13

B. Alternative Compliance 14

C. Penalty for Noncompliance 14

IV. ASSESSING BANK COMPLIANCE TO THE MICRO, SMALL, AND MEDIUM ENTERPRISE MAGNA CARTA

A. Data Sources $\quad 15$

B. Descriptive Statistics of Aggregate Lending 16

C. Aggregate Direct Lending to Micro, Small, and Medium Enterprises 19

D. Direct Compliance versus Alternative Compliance 20

E. Bank-Level Data and Descriptive Statistics $\quad 21$

V. $\quad$ RECENT DEVELOPMENTS AND POLICY IMPLICATIONS 37

$\begin{array}{lll}\text { VI. CONCLUSION } & 38\end{array}$

$\begin{array}{ll}\text { APPENDIX } & 41\end{array}$

BIBLIOGRAPHY 


\section{TABLES AND FIGURES}

\section{TABLES}

1 Definitions of MSMEs in the Philippines 3

2 Profile of Firms in the Philippines, 2011

3 SMEs' Sources of Funding 4

4 Evolution of Asset-Based Definition of MSMEs 6

5 Mandatory Share of MSME in Banks' Loan Portfolio 6

6 Total Resources of the Philippine Financial System 8

7 Minimum Capitalization Requirement by Bank Type in the Philippines 9

$8 \quad$ Financial Indicators and Bank Network (units) by Bank Type, Philippines, 2012

9 Penalty Matrix 15

10 Summary Statistics of MSME Lending According to Firm Size and Bank Type

11 Frequency of Bank Direct Compliance to the Magna Carta Targets across Bank Types in the Philippines, 2005-2010 26

\section{FIGURES}

$1 \quad$ Bank Lending to MSMEs 17

$2 \quad$ Bank Lending to MSMEs, by Type of Enterprise 17

3 Bank Lending to MSMEs, by Type of Enterprise and Bank 18

$4 \quad$ Bank Lending to MSMEs, by Type of Bank 20

5 Distribution of Direct and Indirect Lending to MSMEs, by Type of Bank 21

$6 \quad$ Share of UKBs Not Directly Complying with the Magna Carta 22

$7 \quad$ Share of THBs Not Directly Complying with the Magna Carta 23

$8 \quad$ Kernel Density Estimates of MSME Loans, 2005-2010 27

9 Distribution of Loan Allocation to Micro and Small Enterprises, 2005-2010 28

10 Distribution of Loan Allocation to Medium Enterprises, 2005-2010 29

11 Median Values of Bank MSE and ME Firm Financing, 2005-2010 31

12 Percentile Values of Loans to Micro and Small Enterprises, 2005-2010 32

13 Percentile Values of Loans to Medium Enterprises, 2005-2010 34

14 Median Values of Loans to Micro and Small Enterprises, by Lending Levels in 2005-2007

15 Median Values of Loans to Medium Enterprises, by Lending Levels in 2005-2007 


\begin{abstract}
We examine the effects of a mandated credit program to small and medium enterprises in the Philippines (Magna Carta Law) using a panel dataset compiled from official data published by the Bangko Sentral ng Pilipinas. The final sample of 109 financial institutions represented over $90 \%$ of total finance sector assets in the Philippines. We highlight three important findings. First, although the total lending levels to micro, small, and medium enterprises (MSMEs) grew slightly, the percentage shares of loans allocated to MSMEs declined drastically from a peak of $30 \%$ of total loans in 2002 to $16.4 \%$ in 2010. Second, following the upwards revision of the loan target (from $6 \%$ to $8 \%$ ) for smaller firms in 2008 , there was a sharp increase in noncompliance especially amongst universal and commercial banks. Kernel density estimates suggest that the revision of the Magna Carta in 2008 was binding for small firm lending particularly for the universal and commercial banks. On the other hand, total loans to medium enterprises were still more than threefold larger than the targeted $2 \%$. Third, there is an increased heterogeneity in optimal loan portfolio across banks. Most surprisingly, the absolute level of MSME lending by rural and cooperative banks declined since 2008. Direct compliance amongst universal and commercial banks decreased beginning in the late 2007, while that of thrift banks increased to almost 100\%. Abolishing the Magna Carta targets for medium-sized enterprise loans would most likely yield little adverse effects. Meanwhile, efforts to improve financial access to MSMEs should focus on alternative nondistortionary ways to increase financing supply, such as improving institutional framework for informational availability and development of equity and bond markets for MSMEs.
\end{abstract}

Keywords: financial inclusion, financial markets, financial policy, Philippines, SME, targeted lending

JEL Classification: G21, G28, O16 


\section{INTRODUCTION}

Micro, small, and medium enterprises (MSMEs) is the lifeblood of most economies. A vibrant MSME sector is essential in spreading the economy's wealth and income flows, creating more opportunities in the countryside, maintaining social stability, and fostering inclusive economic growth. In this context, access to finance is central to MSME development. Availability and cost of funds determine firms' ability to compete for market share, innovate, expand and withstand business-related stresses. However, since financial markets in most developing economies are largely underdeveloped with far from ideal regulatory frameworks, many governments in developing Asia have designed medium and long-term MSME development plans, with the main goal of improving financing for MSMEs.

In the Philippines, one of the most important inclusive financing policies is the mandated credit program known as the MSME Magna Carta (Magna Carta) to improve financial access to MSMEs, which account for $99.6 \%$ of total firms and $61 \%$ of total employment in the Philippines. A recent study of the Philippines found that access to formal sector financing is indeed one of the key constraints that strongly affect firms' dynamism (see Khor, Sebastian, and Aldaba 2013). At the same time, MSMEs do not have easy access to the equities nor bonds market.

The overarching objective of the Magna Carta legislation was to "promote, support, strengthen and encourage the growth and development of MSMEs in all productive sectors of the economy particularly rural/agri-based enterprises." The Magna Carta was first enacted and implemented in 1991 (courtesy of Republic Act 6977) - a time when the authorities were grappling for ways to resurrect an ailing economy following a decade or so of tumultuous business climate. In the subsequent 20 years, the law was amended twice to take into account the changes in the business and economic conditions.

The Magna Carta mandated banks to allot a certain portion (10\%) of their loan portfolio to MSMEs. Although not explicitly mentioned, there are at least three good reasons why the regulation specifically targeted banks. Firstly, banks hold the biggest stock of financial resources in the economy amounting to over three quarters of the domestic financial resources. Secondly, banks do have the most extensive network of offices among credit intermediaries. Lastly, banks are easier to monitor since they regularly report their activities to the central bank. While there were questions raised on the rationale of the policy, Medalla and Ravallo (1997) argued that this kind of measure can be justified from a social standpoint since otherwise, banks are driven to channel funds to projects that generate high private returns but not necessarily social returns.

Mandated credit program such as the Magna Carta is not unique to the Philippines. Lending targets set for priority sectors, including small and medium enterprises (SMEs), are imposed in developing economies such as Afghanistan, India, Pakistan, and Sri Lanka. The Magna Carta is also not the first mandated credit provision imposed on Filipino banks. In 1974, the central bank directed banks to allot a portion of their loan portfolio to the agriculture sector via Circular No. 408. ${ }^{2}$ This central bank issuance eventually became known as the Agri-Agra Law (AAL) and continues to be an active regulation to date. ${ }^{3}$

\footnotetext{
Republic Act No. 9501. Magna Carta for Micro, Small, and Medium Enterprises (MSMEs). http://www.lawphil.net/ statutes/repacts/ra2008/ra_9501_2008.html

2 This was a circular issued by the Central Bank of the Philippines, which was renamed Bangko Sentral ng Pilipinas in 1993.

3 BSP Circular 736-2011 and the Agri-Agra Reform Credit Act of 2009 (RA 10000).
} 
How has the Magna Carta impacted banks' lending towards MSMEs? Surprisingly, literature assessing the implementation of the law and its economic impact is very limited. Medalla and Ravallo (1997) assessed the way banks responded to the AAL and the Magna Carta. The authors found out that between 1975 and 1996, AAL compliance ratios had continuously declined. It added that compounded annual growth (CAGR) of AAL loans during the period is roughly 3 percentage points lower than the CAGR of the banks' total loan portfolio. They also mentioned that until 1988, banks have taken advantage of alternative compliance in the form of special series treasury bills that masked the degree of decline in lending such that when it was removed, the drop in lending became very apparent. The authors also noted that from 1991 to 1996, aggregate compliance ratios to the Magna Carta by bank type remained above what the law requires by a good margin. They just highlighted that foreign banks tend not to comply with the law on a consistent basis and are drawn toward alternative compliance mechanisms rather investing directly in firms in spite of the general trend in the industry that is skewed heavily on direct lending.

Furthermore, little is known on the compliance with Magna Carta beyond 1996. This paper is thus undertaken to investigate the patterns of bank lending to MSME in the Philippines after the 2008 Global Financial Crisis and in conjunction to that, the compliance of banks to the Magna Carta lending provisions post 1996. We will also attempt to shed light on the characteristics of banks base on their lending exposure to the MSMEs in terms of bank type, ownership, geographic region, and initial levels of compliance. To our knowledge, this is the first publicly available study on MSME lending in the Philippines from banks' perspective.

This paper is organized as follows: Section II briefly describes the domestic financial market conditions, the customary sources of credit of MSMEs in the Philippines and the government initiatives to boost MSME financing particularly the Magna Carta. Section III will layout the salient features of the lending provisions of the Magna Carta. Section IV will assess the trends of bank lending to MSMEs as well as their compliance to the lending provisions of the Magna Carta using the datasets compiled by the central bank of the Philippines, Bangko Sentral ng Pilipinas (BSP) up to end of 2012. Section V will explain recent developments that could potentially influence banks' lending behavior concerning MSMEs in the near term. Section VI will summarize the key findings of this paper.

\section{FINANCING MICRO, SMALL, AND MEDIUM ENTERPRISES IN THE PHILIPPINES}

\section{A. Definitions}

MSMEs in the Philippines are defined in two ways. The first definition is based on employment levels used by the National Statistics Office (NSO). The second definition is based on asset values used by the BSP (Table 1). This presents a challenge when we examine data on MSMEs financing since there exists no harmonized supply and demand-side dataset. Credit demand-side data on firms are usually based on employment clusters since these datasets (e.g., profile of MSMEs) are mostly compiled by the NSO. On the other hand, credit supply-side data (e.g., lending of banks) are typically based on asset clusters defined by the BSP since reporting banks have to follow the BSP's framework. 
Table 1: Definitions of MSMEs in the Philippines

\begin{tabular}{lll}
\hline Firm Type & $\begin{array}{l}\text { NSO, Employment Level Range } \\
\text { (number of employees) }\end{array}$ & BSP, Asset Size Range (P) \\
\hline Micro & $1-9$ & $<3,000,000$ \\
Small & $10-99$ & $3,000,001-15,000,000$ \\
Medium & $100-199$ & $15,000,001-100,000,000$ \\
Large & $>200$ & $>100,000,00$ \\
\hline
\end{tabular}

BSP = Bangko Sentral ng Pilipinas, MSME = micro, small, and medium enterprise, NSO = National Statistics Office. Sources: SMED Council Resolution No. 1 (2003); Republic Act 9501 (2008).

MSMEs comprise almost all of the total number of firms in the Philippines. Based on the 2011 survey data from the NSO $90.6 \%$ were microenterprises (Table 2). They employ roughly $61 \%$ of the total employees in the economy. This distribution profile hardly changed in the last 10-15 years. In spite of their enormous number, however, MSMEs only contributed 35.7\% to gross domestic product (GDP) in 2011 (Clavesillas 2013). ${ }^{4}$

In terms of industry concentration, they are largely found in wholesale, retail, and trade segment. As regards their location, over $50 \%$ of them are located in the National Capital Region (NCR), Region 3 (Central Luzon region), and Region 4A (Calabarzon region) ${ }^{5}$-the top three regions in terms contribution to the national GDP. ${ }^{6}$

Table 2: Profile of Firms in the Philippines, 2011

\begin{tabular}{lrrrrr}
\hline & Micro & Small & Medium & Large & MSME \\
\hline Number of firms & 743,250 & 70,222 & 3,287 & 3,496 & 816,759 \\
Share (\%) & 90.6 & 8.6 & 0.4 & 0.4 & 99.6 \\
& & & & & \\
Employment (million) & 1.78 & 1.64 & 0.45 & 2.47 & 3.87 \\
Share (\%) & 28.0 & 25.9 & 7.1 & 39.0 & 61.0 \\
& & & & & \\
Firm distribution by industry (\%) & & & & & \\
Wholesale, retail, and trade & 48.7 & 29.8 & 16.9 & 11.3 & 47.0 \\
Manufacturing & 13.6 & 14.3 & 27.4 & 29.3 & 13.7 \\
Accommodation and food service & 12.6 & 16.0 & 5.8 & 2.4 & 12.9 \\
Others & 25.1 & 39.9 & 49.9 & 57.0 & 26.5 \\
& & & & & \\
Regional location, firm distribution (\%) & & & & & \\
National Capital Region & 24.2 & 43.2 & 45.0 & 46.3 & 26.0 \\
Region 3 & 10.3 & 8.8 & 8.1 & 5.6 & 10.2 \\
Region 4A & 15.4 & 11.1 & 14.1 & 17.5 & 15.0 \\
Others (13 regions) & 50.0 & 36.9 & 32.9 & 30.5 & 48.8 \\
\hline
\end{tabular}

MSME = micro, small, and medium enterprise.

Source: National Statistics Office.

4 The 2008 figure is the most recent estimate of MSMEs' share in GDP. In the SME Development Plan 2011-2016, the government targets to push the contribution of MSMEs to $40 \%$ of GDP.

5 There are 16 regions in the Philippines.

6 In 2012, the NCR, Region 3, and Region 4A accounted for $62 \%$ of the GDP. 


\section{B. Sources of Credit}

Firms' need for additional capital is typically addressed by (i) banks; (ii) bonds market; (iii) equities market; (iv) nonbank lending institutions like quasi banks and investment houses, pawnshops, financing cooperatives, savings and loans associations, insurance companies, venture capitalists, and specialized government lending corporations; and ( $v$ ) informal sector players, such as family members, friends, and unaccredited retail lenders.

Just like in many developing economies, MSMEs in the Philippines have limited access to the equities market. MSMEs accounted for a mere $0.005 \%$ of total market capitalization by end of 2012, and are also not considered reputable enough to enter the bonds market. ${ }^{7}$ Other large scale credit sources like quasi banks, investment houses, and insurance companies typically also shy away from MSME clients while the role of venture capital firms remain quite small. Thus, given that access to formal financing is relatively scarce for MSMEs, capital options usually narrow to informal sectors, such as financing cooperatives, savings and loans associations, pawnshops, and informal sector lenders.

Assessments of credit provisions suggest that MSMEs depend more on their internally generated resources to bankroll their operations (Table 3), while formal financial institutions only contribute somewhere between $11 \%$ and $21 \%$ of the MSMEs' capital utilization. The lack of reliable financial information from MSMEs leads to the perception of higher risk. In addition, lower expected profitability, the absence of "acceptable" collateral by MSMEs, the lack of a national credit rating system for MSMEs contribute to the low loan releases from banks to the sector.

Table 3: SMEs' Sources of Funding (\% of current funding)

\begin{tabular}{lccccc}
\hline & SERDEF-UP ISSI, & WBES, & ICPS-ADB, & PEP-IFC, & WBES, \\
& 1992 & 2000 & 2004 & 2006 & $2009^{\mathrm{a}}$ \\
\hline Own resources & 78 & 52 & 60 & 69 & 76.4 \\
Bank loans & 15 & 21 & 11 & 19 & 10.2 \\
Nonbank financial institution & & & & & 0.9 \\
Informal credit $^{b}$ & 7 & 27 & 29 & 12 & 12.4 \\
\hline Total & 100 & 100 & 100 & 100 & 100 \\
\hline
\end{tabular}

ICPS-ADB = Investment Climate and Productivity Study, Asian Development Bank, PEP-IFC = Private Enterprise Partnership for the Philippines (PEP-Philippines) SME Financing Survey, International Finance Corporation, SERDEF-UP ISSI = Small Enterprise Research and Development Foundation-University of the Philippines Institute for Small Scale Industries; SME = small and medium enterprise, WBES = World Bank Enterprise Survey.

a Shares in the firms' working capital.

b Purchases on credit from suppliers/advances from customers + loans from moneylenders, friends, and relatives.

Sources: Nangia and Villancourt 2007; WBES 2009

7 By the end of December 2012, the declared market capitalization of SMEs in the Philippine stock exchange is P586.4 million ( $\$ 14.2$ million) whereas the total market capitalization is P10.9 trillion ( $\$ 265.3$ billion). 


\section{The Micro, Small, and Medium Enterprise Magna Carta}

In an effort to aid MSMEs with their credit needs, the Philippine authorities crafted a legislation that mandated banks to allocate $10 \%$ of their lending portfolio to MSMEs. The MSME Magna Carta, as it is commonly known, also laid out a number of important parameters and measures in support of its main objective. Some of these measures are as follows:

(i) It compartmentalized enterprises according to asset size and laid out a coordinated structural support and safeguards system to enhance growth of enterprises classified under micro, cottage, small, and medium;

(ii) It streamlined business procedures and requirements, made government services readily available to businesses outside the centers of commerce, and "incentivized" financing to the MSMEs;

(iii) It created the Small and Medium Enterprise Development Council ${ }^{8}$ as an attached agency of the Department of Trade and Industry to carry out the objectives of the law and appointed the Bureau of Small and Medium Enterprises Development (BSMBD) ${ }^{9}$ as the council secretariat;

(iv) It stipulated monetary and nonmonetary incentives and directed government banks (at that time include the Philippine National Bank, the Development Bank of the Philippines and the Land Bank of the Philippines) to provide financing assistance to entrepreneurs under these groups; and

(v) It created the Small Business Guarantee and Finance Corporation (SBGFC) to improve production operations and business network of firms, to provide financial services to small and medium enterprises (except those involved in trading and crop-level production) and develop alternative modes of financing and guarantee loans secured by "qualified SMEs." The SBGFC and the Guarantee Fund for Small and Medium Enterprises ${ }^{10}$ were merged in November 2001 to form the Small Business Corporation (SBC) to consolidate their resources." The new SBC and the much older Philippine Export-Import Credit Agency are presently the two main agencies charged to assist SMEs (which was later expanded to MSMEs) when it comes to their finances. ${ }^{12}$

The Magna Carta specifically targeted banks given that they hold over $75 \%$ of total financial sector's assets in the Philippines. In addition, banks have an extensive network of offices and credit channels and are administratively easier to monitor since banks have to regularly report their activities to the central bank.

The Magna Carta was amended twice (RA 6977 amended by RA 8289 and RA 9501) in an effort to make the legislation in tune with the changes in firms' needs and the economic conditions. In

8 This agency was later renamed as the Micro, Small, and Medium Enterprise Development Council (MSMEDC).

9 This bureau was later renamed as Bureau of Micro, Small and Medium Enterprises Development (BMSMED).

10 The Guarantee Fund for Small and Medium Enterprises was established in 1984 operated by the Livelihood Corporation attached to the office of the president tasked to provide guarantee services to participating financial institutions (PFIs) that had been lending to SMEs. (ADB 2010)

11 The agency which was put under the supervision of the central bank has a board comprised of representatives both from the private sector and the public sector, namely the National Government, Land Bank of the Philippines, Development Bank of the Philippines, Department of Trade and Industry, and Department of Finance (DOF).

12 The Philippine Export-Import Credit Agency (PhilEXIM) was established in 1977 under the DOF, to pursue the policy of the State "to encourage and promote the expansion of Philippine exports and to establish a strong and credible export credit institution, which shall be dedicated to the provision of export financing facilities and services to support the country's sector (See PhilEXIM's website). See also ADB (2005). 
particular, the thresholds for asset-based enterprise classification were significantly adjusted in 1997 and 2002. The thresholds for micro and medium firms changed the most, approximately tripling between 1991 and 1997, and roughly doubling between 1997 and 2002 (Table 4). These variations would prove to be very important to banks in their compliance to the mandated lending provision of the law. The increased thresholds mean that their target market for MSMEs had also increased in size.

\section{Table 4: Evolution of Asset-Based Definition of MSMEs}

\begin{tabular}{lccrrrr}
\hline $\begin{array}{l}\text { Law/ } \\
\text { Regulation }\end{array}$ & $\begin{array}{c}\text { Year } \\
\text { Enacted }\end{array}$ & Micro & Cottage & $\begin{array}{c}\text { Small } \\
(\mathrm{P})\end{array}$ & Medium & Large \\
\hline RA 6977 & 1991 & $<50,000$ & $50,001-$ & $500,001-$ & $5,000,001-$ & $>20,000,000$ \\
& & & 500,000 & $5,000,000$ & $20,000,000$ & \\
RA 8289 & 1997 & $<1,500,001$ & & $1,500,001-$ & $15,000,001-$ & $>60,000,000$ \\
& & & & $15,000,000$ & $60,000,000$ & \\
SMED Council $^{a}$ & 2003 & $<3,000,000$ & & $3,000,001-$ & $15,000,001-$ & $>100,000,00$ \\
and RA 9501 $^{2}$ & 2008 & & & $15,000,000$ & $100,000,000$ & \\
\hline
\end{tabular}

MSME = micro, small, and medium enterprise; RA = Republic Act; SMED = Small and Medium Enterprise Development.

a Refers to SMED Council Resolution No. 1 (2003).

In addition, the coverage of the law and the statutory share of MSMEs in bank lending have also changed over the years (Table 5). While the required ratio has fluctuated between 5\% and 10\% since 1991, the mandated coverage has continually increased beyond small firms. The revision in 1997 extended coverage to medium firms. The law also recognized that medium firms are fundamentally different from smaller firms, hence the establishments of two separate compliance rates for medium and smaller firms. By the last revision in 2008, the law was extended to cover microenterprises. While the 2008 revision also further distinguished microenterprises from other small enterprises, the compliance rates for small and micro were still aggregated into the same category under the law. As of the 2008 revision, the law mandates all banks to allocate $2 \%$ of their total loan portfolio to medium firms, and a further $8 \%$ to micro and small firms.

Table 5: Mandatory Share of MSME in Banks' Loan Portfolio

\begin{tabular}{|c|c|c|c|}
\hline Law & $\begin{array}{c}\text { Year } \\
\text { Enacted }\end{array}$ & Coverage (enterprises) & $\begin{array}{c}\text { Share in Banks' Loan Portfolio } \\
\text { (years in effect) }\end{array}$ \\
\hline RA 6977 & 1991 & Small & $\begin{array}{l}\text { 5\% (1991); 10\% (1992-1995); 5\% } \\
\text { (1996); 0\% (1997) }\end{array}$ \\
\hline RA 8289 & 1997 & Small and medium & $\begin{array}{l}\text { Small: 6\% (1997-2007) }{ }^{\mathrm{a}} \\
\text { Medium: 2\% (1997-2007) }\end{array}$ \\
\hline $\begin{array}{l}\text { RA 9501; } \\
\text { BSP Circular } 625 \text { (2008) }\end{array}$ & 2008 & Micro, small, and medium & $\begin{array}{l}\text { Micro and Small: 8\% (2008-2018) } \\
\text { Medium: } 2 \%(2008-2018)^{\mathrm{a}}\end{array}$ \\
\hline
\end{tabular}

$\mathrm{BSP}=$ Bangko Sentral ng Pilipinas; MSME = micro, small, and medium enterprise; RA = Republic Act.

a RA 8289 should have ended in May 2007 but implementation of the lending provision was extended until early December 2008 (BSP Circular Letter 2007-039) because the BSP issued circular 625-2008 pursuant to RA 9501 only on 14 October 2008, which became effective 15 days after it was published on 20 October 2008.

In the present form of the law, firms considered eligible to be covered by the law have to satisfy the following four conditions. First, firms need to be registered with the appropriate agencies as presently provided by law. Second, firms should be fully (100\%) owned, capitalized by Filipino citizens, whether single proprietorship or partnership. If the enterprise is a juridical entity, at least $60 \%$ of its capital or outstanding stocks must be owned by Filipino citizens. Third, firms should be participating in a business activity within the major sectors of the economy, namely, industry, trade, services, including 
the practice of one's profession, the operation of tourism-related establishments, and agribusiness. Lastly, eligible firms are those that are not a branch, subsidiary or division of larger scale enterprises. ${ }^{13}$

\section{Other Initiatives to Encourage Lending to Micro, Small, and Medium Enterprises}

To keep bank funds flowing steadily to the MSME sector, the BSP also instituted a number of measures to compensate lending institutions for the burden brought about by the Magna Carta. ${ }^{14}$ These include:

(i) Allowing the establishment of microfinance-oriented thrift banks and rural banks as an exemption from branching moratorium (Circular No. 273 dated February 27, 2001);

(ii) Exemption of microfinance loans from normal documentation applicable to regular bank loans (Circular No. 273 dated February 27, 2001);

(iii) Reduction of the reserve requirements on thrift banks and rural banks which deal with SMEs and small borrowers (Circular No. 363 dated December 3, 2002);

(iv) Reduction of the risk weight applicable to qualified SMEs and microfinance loan portfolios from 100\% to 75\% subject to certain conditions (Circular No. 364 dated 9 January 2003), such as performance and financial soundness of the bank and adequacy of risk management system;

(v) Exemption of SME loans without latest income tax returns and/or audited financial statements from "Loans Especially Mentioned" classification provided said loans are current, have not been restructured, and are supported by income tax return and/or audited financial statement at the time they were granted;

(vi) Deferment, for a period of 1 year, of the implementation of the market-based pricing mechanism for rediscount loans below the 91-day Treasury bill rate to help jumpstart SME lending; and

(vii) Approval of the 12-point accreditation guidelines for rural and thrift banks and the lending features of short- and long-term loans for direct or retail lending by participating government financial institutions under the SME Unified Lending Opportunities for National Growth (SULONG).

The government also focused on aspects that would make banking nonlarge firms appealing to the creditor, such as (ii) establishing an effective loan guarantee system, (i) finding ways to deal with collateral requirement issues, (iii) creating a public credit bureau, (iv) developing more appropriate ways to assess risk associated with lending to SMEs, and ( $v$ ) optimizing the network of state-owned firms in delivering services to SMEs.

In order to alleviate information gaps, one important solution considered by both regulators and financial institutions is the creation of a reliable credit scoring system to assess the credit viability of firms that can be used by the entire banking system. Notably, according to an ADB report (2004), "SBC's management has discovered (as have many other lenders in many places) that there is no clear correlation between the kind and quality of collateral offered to a lender and loan default. This implies that loan underwriting techniques that do not rely on traditional collateral are highly relevant in the Philippines."

13 "This requirement shall not preclude MSMEs from accepting subcontracts and entering into franchise partnership with large enterprises or from joining in cooperative activities with other MSME" (RA 9501).

14 BSP Media Release (2 February 2004). 
To further strengthen its overall approach to facilitate financing for SMEs, the government implemented the SME Unified Lending Opportunities for National Growth (SULONG) program. The SULONG program, launched in 2003, essentially sought to provide SMEs alternative credit sources through participating government financial institutions. ${ }^{15}$ The general objectives of the program were to: (i) simplify and standardize the lending procedures, (ii) reduce documentary requirements and expedite procedures, (iii) provide SMEs greater access to short- and long-term funds, and (iv) lower the effective cost of borrowing by SMEs and liberalize the requirement. ${ }^{16}$

Finally, the BSP also rolled out the Credit Surety Fund program on 2 July 2008. The rationale of this fund is "to increase the credit worthiness MSMEs that are experiencing difficulty in obtaining loans from banks due to lack of acceptable collaterals, credit knowledge and credit track records" (BSP, 2013b). Essentially, the Credit Surety Fund can serve as: (i) an alternative to acceptable collaterals, (ii) security for loans of MSMEs that are members of a cooperative, and (iii) an assurance for payment of bank loans. Investors in the fund are comprised of cooperatives, nongovernment organizations, local government units, banks (e.g., Development Bank of the Philippines, Land Bank of the Philippines, and Industrial Guarantee and Loan Fund), donors, and the BSP. Eligible borrowers include MSMEs who are members of cooperatives and who have businesses that meet certain conditions. ${ }^{17}$

\section{E. The Structure of the Banking Industry in the Philippines}

The banking industry in the Philippines forms the core of the financial system in the Philippines. By end of 2012, banks hold $80 \%$ of the approximately P10 trillion of total domestic financial assets. ${ }^{18}$ Nonbanks, which include investment houses and companies, finance companies, securities dealers and brokers, pawnshops, lending investors, nonstock savings and loan associations, venture capital corporations, private and government insurance companies, and credit card companies accounted for the remaining $20 \%$. For the last 3 decades this distribution hardly changed, despite a fivefold growth in total financial assets from 1990 to 2000, and another 2.5-fold growth from 2000 to 2012 (Table 6).

Table 6: Total Resources of the Philippine Financial System (P billion)

\begin{tabular}{lrrrrcr}
\hline Year & \multicolumn{1}{c}{ Total } & UKB $^{\mathrm{a}}$ & THB $^{\mathrm{b}}$ & $\mathrm{RCB}$ & Total Banks & Nonbanks $^{\mathrm{c}}$ \\
\hline 1970 & 18.8 & 17.2 & 0.9 & 0.7 & 18.8 & \\
1980 & 248.1 & 172.6 & 10.6 & 5.6 & 188.8 & 59.3 \\
1990 & 800.2 & 558.2 & 37.6 & 13.9 & 609.7 & 190.5 \\
2000 & $4,077.9$ & $3,013.6$ & 245.8 & 67.4 & $3,326.7$ & 751.1 \\
2010 & $9,046.3$ & $6,423.7$ & 626.4 & 180.1 & $7,230.2$ & $1,816.1$ \\
2012 & $10,516.2$ & $7,486.7$ & 681.6 & 190.1 & $8,358.3$ & $2,157.8$ \\
\hline
\end{tabular}

$\mathrm{RCB}=$ rural and cooperative bank, $\mathrm{THB}=$ thrift bank, $\mathrm{UKB}=$ universal and commercial bank.

a Includes specialized government banks.

b Includes savings and mortgage banks, private development banks, and stock savings and loan associations.

c Includes investment houses, finance companies, investment companies, securities dealers/brokers, pawnshops, lending investors, nonstock savings and loan associations., venture capital corporations, credit card companies, which are under BSP supervision, and private and government insurance companies (e.g., Social Security System and Government Service Insurance System).

Source: Bangko Sentral ng Pilipinas.

15 These include the Development Bank of the Philippines, Land Bank of the Philippines, Small Business Guarantee Corporation, and the Social Security System.

16 Both the Development Bank of the Philippines and Land Bank of the Philippines are part of the SULONG program.

17 See BSP (2013c) for the details.

18 This is approximately equivalent of $\$ 250.4$ billion, based on the exchange rate of P42 per US dollar. 
Overall, banks in the Philippines are supervised by the BSP as prescribed by the General Banking Law passed in 2000 (also known as RA 8791). The law also classified banks in the Philippines as universal banks, commercial banks, thrift banks, rural and cooperative banks, or Islamic banks. The Monetary Board, which is the decision-making body of the central bank, may also create another type of bank if the need arises. The minimum capitalizations are highest for universal banks (P4.95 billion), followed by commercial banks (P2.4 billion), thrift banks (P1 billion for those headquartered in Manila and P250 million for others). The minimum capital requirement for rural banks and cooperatives are much lower, ranging from P100 million for those headquartered in Manila to below P5 million for those based in rural 5th-6th class municipalities (Table 7). In our subsequent analysis, we group all these institutions into three broad groups: universal and commercial banks (UKBs), thrift banks (THBs or thrifts), and rural and cooperative banks (RCBs or rural co-ops). The average UKB has approximately 20 times the assets of the average thrift bank, which in turn has average total assets 20 times the average rural and cooperative banks.

Table 7: Minimum Capitalization Requirement by Bank Type in the Philippines

\begin{tabular}{lccc}
\hline Bank Type & \multicolumn{2}{c}{ Minimum Capitalization } & $\begin{array}{c}\text { Additional Major Statutes aside from } \\
\text { the General Banking Law }\end{array}$ \\
\cline { 2 - 3 } Universal $^{\text {be }}$ & P billion & 120.17 & \\
Commercial $^{\text {ce }}$ & 4.95 & 58.26 & Thrift Banks Act (RA 7906) \\
Thrift $^{\text {d }}$ & 2.40 & & \\
$\quad$ Head Office: & & 24.28 & \\
Metro Manila & 1.00 & 12.14 & \\
Cities of Cebu and Davao & 0.50 & 6.07 & \\
Other areas & 0.25 & & Rural Banks Act (RA 7353) \\
Rural & & & \\
Head Office: & & 2.43 & \\
Metro Manila & 0.10 & 1.21 & \\
Cities of Cebu and Davao & 0.05 & 0.61 & \\
Other cities & 0.025 & 0.24 & \\
1st-4th class municipalities & 0.01 & 0.12 & \\
5th-6th class municipalities & 0.005 & 0.24 & Cooperative Code (RA 6938) \\
Cooperative & 0.010 & & \\
\hline
\end{tabular}

RA = Republic Act.

a 2012 end-of-period $\mathrm{P} / \$$ exchange rate is 41.1920 .

b Includes Al-Amanah Islamic Investment Bank of the Philippines (AAIB), which is the only Islamic Bank in the country at present. AAIB is governed by its own charter, i.e., Charter of Al-Amanah Islamic Investment Bank of the Philippines (RA 6848). Includes specialized government banks.

d Includes savings and mortgage banks, private development banks, and stock savings and loan associations.

e See General Banking Law of 2000 for the features delineating universal and commercial banks. A summary of these features is listed under Section X101 of the Manual of Regulations for Banks, Volume 1.

Source: Bangko Sentral ng Pilipinas. 2011e. Manual of Regulations for Banks. Volume 1. Manila. December.

As of end of 2012, there were a total of 696 formal banks in the Philippines, of which 36 are UKBs, 70 are THBs, 589 are RCBs, and 1 Islamic Bank (which is also classified by the BSP as a UKB). Although universal and commercial banks were the least numerous out of the three broad banking classifications, they have the most extensive branch networks and hold the biggest proportion of banking resources (e.g., asset, loans, deposits, and capital). All of the 37 UKBs accounted altogether for $89.4 \%$ of total banking assets, $86.3 \%$ of total loans, $88.6 \%$ of total deposits, as well as $54.7 \%$ of total 
bank offices around the country. Within this UKB group, there was also a huge dispersion in terms of resources: the biggest 10 UKBs housed $74.4 \%$ of the segment's assets, release $74.3 \%$ of the segment's loans, handle $71.9 \%$ of the segment's deposits, and operate $83.7 \%$ of all the segment's offices. In other words, two-thirds of the Philippines' total financial assets and loans were concentrated in the top 10 universal and commercial banks in the country. ${ }^{19}$

Compared to the universal and commercial banks, the other banking institutions in the Philippines were comparatively much smaller. Rural and cooperative banks, which accounted for $84.6 \%$ of all banking institutions (589 institutions out of 696 total in 2012), only accounted for $2.4 \%$ banking sector's value, $3 \%$ of total lending, $2.2 \%$ of total deposits while running just $28.1 \%$ of all the banking counters nationwide. Thrift banks, which were represented by 70 institutions, hold only $8.3 \%$ of the sector's total assets, disburse $10.7 \%$ of total loans, and manage $9.2 \%$ deposits through their 1,619 bank offices (17.2\% of total) (Table 8 ).

Table 8: Financial Indicators and Bank Network (units) by Bank Type, Philippines, 2012

\begin{tabular}{lrrrrrrr}
\hline Level (P billion) & Assets & Loans & Deposits & Capital & Head Office & Branches & $\begin{array}{c}\text { Total } \\
\text { Offices }\end{array}$ \\
\hline UKB ${ }^{\text {a }}$ & $7,193.8$ & $3,617.2$ & $5,097.5$ & 937.1 & 37 & 5,108 & 5,145 \\
of which: Top 10 & $5,350.2$ & $2,686.6$ & $3,931.1$ & 673.6 & 10 & 4,297 & 4,307 \\
THB & 666.2 & 446.6 & 529.8 & 81.1 & 70 & 1,549 & 1,619 \\
RCB & 189.7 & 127.5 & 126.4 & 33.3 & 589 & 2,057 & 2,646 \\
Total & $8,049.7$ & $4,191.3$ & $5,753.6$ & $1,051.5$ & 696 & 8,714 & 9,410 \\
\hline Distribution (\%) & & & & & & & \\
\hline UKB & 89.4 & 86.3 & 88.6 & 89.1 & 5.3 & 58.6 & 54.7 \\
of which: Top 10 & & & & & & & \\
\% of UKB & 74.4 & 74.3 & 77.1 & 71.9 & 27.0 & 84.1 & 83.7 \\
\% of Total & 66.5 & 64.1 & 68.3 & 64.1 & 1.4 & 49.3 & 45.8 \\
THB & 8.3 & 10.7 & 9.2 & 7.7 & 10.1 & 17.8 & 17.2 \\
RCB & 2.4 & 3.0 & 2.2 & 3.2 & 84.6 & 23.6 & 28.1 \\
\hline
\end{tabular}

$\mathrm{RCB}=$ rural and cooperative bank, $\mathrm{THB}=$ thrift bank, $\mathrm{UKB}=$ universal and commercial bank.

${ }^{a}$ Al-Amanah Islamic Investment Bank of the Philippines is subsumed under UKB (per BSP directory of Banks).

Sources: Bangko Sentral ng Pilipinas; Annual Reports and Press Releases of the top 10 banks (by asset size) for the number of branches.

In general, each category of banks operate in distinct markets, though the market niches are starting to overlap. Rural and cooperative banks typically focused on retail clients and microloans in the countryside. The universal and commercial banks, on the other hand, serve as the primary arteries of credit for larger urban firms and are usually part of a bigger conglomerate groups themselves. ${ }^{20}$

19 The top 10 universal and commercial banks by asset size in 2012 were: BDO Unibank Inc., Metropolitan Bank and Trust Company, Bank of the Philippine Islands, Land Bank of the Philippines, Development Bank of the Philippines, Philippine National Bank, China Banking Corporation, Rizal Commercial Banking Corporation, Union Bank of the Philippines, and Security Bank Corporation.

20 However, the BSP has prescribed limitations to loans, other credit accommodations and guarantees to directors, officers, stockholders, and their related interests (DOSRI). Based on the Manual of Regulations for Banks of 2011 (Sec. X330), the general principle is that "the total outstanding loans, other credit accommodations and guarantees to each of the bank's DOSRI shall be limited to an amount equivalent to their respective unencumbered deposits and book value of their paidin capital contribution in the bank: Provided, however, that unsecured loans, other credit accommodations and guarantees to each of the bank's DOSRI shall not exceed thirty percent (30\%) of their respective total loans, other credit accommodations and guarantees." 
Lastly, the thrift banks, some of which were large enough to compete with universal and commercial banks for big borrowers, normally focus on small and medium enterprises in metropolitan and provincial business centers left unaddressed by the UKBs. It is also important to note that a number of major thrift banks are likewise either affiliates of UKBs or financial arms of big holding companies.

\section{A Brief Political-Economic History of the Philippine Banking Industry}

Prior to extensive structural changes in the last 2 decades, the government has played the role of the primordial driver of the banking sector (as is the case with other key sectors such as aviation, telecommunication, water, power, etc.). ${ }^{a}$ However, political intrusion leading to regulatory lapses and poor oversight had resulted in an unstable industry growth path and severely impacted the government's coffers. The local banking system barely escaped collapse in the 1970s and the early part of 1980s. ${ }^{b}$ The banking crisis of the 1980s was particularly remarkable since it led to the insolvencies of two large investment houses, three commercial banks (including two of the largest banks in the country that are state-owned), and 160 rural and thrift banks (Nascimento 1990). ${ }^{c}$

In 1984 and 1985, a series of difficult economic episodes crippled the domestic capital market and eventually caused the economy to contract. ${ }^{d}$ Capital infusion by the national government kept the banking system afloat while a standby credit arrangement with the International Monetary Fund was needed to restore the credibility of the country in the international financial network - mainly in terms of availability of foreign reserves, albeit at a huge cost to the public (Nascimento 1990, Dohner and Intal, Jr. 1989). Subsequently, the process of reforming the entire industry forced the government to sell to the private sector a substantial amount of its shares in two major banks. ${ }^{e}$ Reform measures also compelled the restructuring and recapitalization of the central bank that itself went bankrupt. ${ }^{f}$

As conditions improved, further liberalization measures were carried out in the first half of 1990s involving entry of foreign banks, bank branching regulations, and foreign exchange transactions. The easing of restrictions resulted in a more fluid movement of capital and, accordingly, a sharp rise in the number of branches in a very short time (See box figure). Nonetheless, the number of banks declined marginally due to continuous market consolidation especially in the rural and cooperative banks segment (Pasadilla and Milo 2005).

Banking Institutions and Branches, 1970-2012

a. Total number of banks

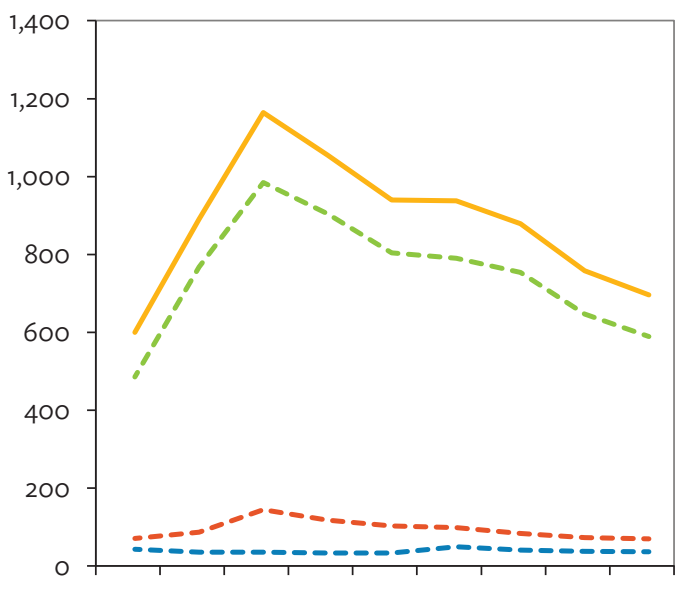

197019751980198519901995200520102012

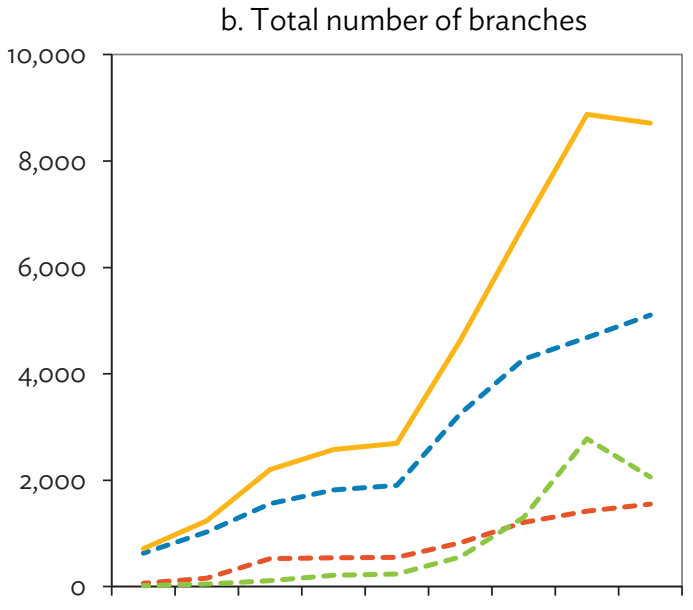

197019751980198519901995200520102012

$$
-\cdots--\cup \text { UKB } \quad-\cdots-- \text { THB }
$$

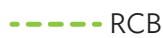

$\mathrm{RCB}=$ rural and cooperative bank, $\mathrm{THB}=$ thrift bank, $\mathrm{UKB}=$ universal and commercial bank 
In addition, just before the turn of the decade, the central bank issued a moratorium on bank branching following the Asian financial crisis. Although the local banking system generally proved to be resilient, the credit crunch and the very steep currency revaluation caused some small banks to fail. Systemwide nonperforming loans also inched up considerably from $2.6 \%$ in 1996 to $17.6 \%$ midway in 2002 . Uncertainties over the length and depth of the impact of the crisis on the local banks have also pushed monetary authorities to operate at very restrictive mode.

In 2000, a new central bank charter was passed into law largely to strengthen the Bangko Sentral ng Pilipinas' (BSP) supervisory and oversight functions as well as to improve its crisis response toolkit. In a nutshell, the General Banking Law (RA 8791), as it is more commonly known, granted the BSP the authority to oversee and administer compliance of banks to applicable laws and regulations, inquire into the solvency and liquidity of financial institutions (e.g., foreign and local banks, quasibanks, and trust entities, and other types of banks), enforce prompt corrective action, determine policy direction in the areas of money, banking and credit, and to the extent feasible, ensure compliance to the internationally accepted standards, including of the Bank for International Settlements.

Restrictions were gradually relaxed as ill-effects of the regional financial turmoil started to wane and as macro and microprudential measures that were erected began to deepen their roots. Banks have likewise become more careful in managing risks in the years following the Asian financial crisis. ${ }^{h}$ Thus, in contrast to the severe impacts of the Asian financial crisis, the recent global financial crisis made a much smaller dent on the books of the banks. 'Such display of financial resilience gave the BSP a much bigger policy room to maneuver without having to take draconian measures in order to keep the spillovers in check. Instead, the central bank opted for a series of policy rate adjustments and a 2 percentage point cut in the statutory reserve requirement to ensure that the system remains liquid. ${ }^{j}$ In 2011 , the BSP likewise removed the last of the branching regulation put in place 12 years earlier to create a more accommodative regulatory structure. ${ }^{k}$

a The Development Bank of the Philippines and the Philippine National Bank (PNB) alone (both state-owned banks at that time) held nearly $50 \%$ of the banking sector's assets before they became insolvent in 1985 (Gochoco-Bautista 1999).

b "After a long era of political intrusion under the Marcos regime, there is a principal-agent problem as regulators and supervisors may not be operating in the public interest. Meanwhile, private banks belong to business conglomerates and do not act tough on affiliated companies since they can expect financial assistance from BSP," (Nasution 1999).

c According to Gochoco-Baustista (1999), the Development Bank of the Philippines and the Philippine National Bank (PNB), which are both government controlled at that time, were declared insolvent owing largely to excessive lending to DOSRI. Nascimento (1990) noted that on top of the economy-related factors, what happened to DPB and PNB was a reflection of politically motivated loans granted sometime in the 1970s until the early 1980s, poor internal controls, auditing, and lending standards, and the decision to take over troubled corporations. The government assumed the liabilities of both banks and PNB was eventually privatized.

$d$ The value of the Philippine peso was cut by more than $50 \%$ within 2 years. Inflation ranged between $33 \%$ and $63 \%$, which lasted for about a year. Dollar reserves slumped to critical levels causing external trade and debt financing problems (balance of payments crisis). On top of these, the assassination of Senator Benigno Aquino in 1983 almost annihilated the positive investment prospects for the country (Nascimento 1990).

e These are PNB and Union Bank. PNB was the biggest bank in the country at that time in terms of assets.

f The Central Bank of the Philippines itself became bankrupt mainly due to the assumption of foreign liabilities and other quasifiscal activities (Singson 1999). After its restructuring in 1993, the Central Bank of the Philippines was renamed Bangko Sentral ng Pilipinas.

g Manlagñit and Lamberte (2004) discuss in greater details the various banking sector reforms undertaken after the Asian financial crisis.

h Banks' NPLs ratio eased from a high of 17.6\% in Q1 2002 to 3.1\% as of Q3 2011 while the sector managed to maintain a healthy capital adequacy ratio-17.4\% as of Q1 2011, well above the statutory requirement of 10\% and the Basel Agreement benchmark of 8\% (See BSP, Reports on Economic and Financial Developments).

BSP Status Reports on the Philippine Financial System, 2nd semester of 2009 and 1st semester 2010

i Overall reserve requirement ratio was cut by 2 percentage points in November 2008, from $21 \%$ to $19 \%$ through a reduction in statutory reserve requirement from $10 \%$ to $8 \%$. The ratio was brought back to $21 \%$ in July 2011 (via two separate increases in statutory reserve requirement from $8 \%$ to $9 \%$ in June 2011 and from $9 \%$ to 10\% in July 2011) but was slashed by 3 percentage points again, from $21 \%$ to 18\% in February 2012 (effective April 2012) designed to offset the impact on banks of reduced revenue stream as the monetary authorities decided to stop interest payments on bank reserves placed with the central bank (referred to as the statutory reserve equivalent to $10 \%$ of banks' deposits). The monetary authorities likewise decided to unify (i.e., no longer makes distinction) liquidity and statutory reserve requirement. (BSP 2012, BSP Circular 732-2011, BSP Circular 726-2011, BSP Circular 632-2008).

k See BSP Circular Letter (10 September 1999), BSP Circular 273-2001, BSP Circular 277-2001, BSP Circular 505-2005, BSP Circular 625-2008, and BSP Circular 728-2011.

Source: Bangko Sentral ng Pilipinas. 


\section{COMPLIANCE TO THE MICRO, SMALL, AND MEDIUM ENTERPRISE MAGNA CARTA}

\section{A. Direct Compliance}

The most important part of the MSME Magna Carta is the legal mandate for mandatory credit allocation (as laid out under Rule 13) that all lending institutions have to set aside 8\% of their total loan portfolio for micro and small enterprises (MSEs), and a further $2 \%$ for medium enterprises (MEs). The BSP allows banks various channels to comply with the mandatory credit allocation for MSMEs. Basically, these can be divided into two categories namely, the direct compliance and the indirect compliance. As stipulated in BSP Circular 625 issued in 2008, ways to comply directly are enumerated below, and vary across the targeted firm size.

For micro and small enterprises:

(i) Actual extension of loans to eligible MSEs, other than to Barangay Microbusiness Enterprises (BMBEs) which are covered in Item "c(3)" hereof: ${ }^{21}$ Provided, however, that loans granted to MSEs other than BMBEs, to the extent funded by wholesale lending of, or rediscounted with, another bank shall not be eligible as compliance with the mandatory credit allocation; or

(ii) Loans granted to export, import, and domestic micro and small scale traders, other than to BMBEs which are covered in Item " $c(3)$ " hereof: Provided, however, that loans granted to MSEs other than BMBEs, to the extent funded by wholesale lending of, or rediscounted with, another bank shall not be eligible as compliance with the mandatory credit allocation; or

(iii) Purchase of eligible MSE loans listed in Items " $\mathrm{c}(1)$ " and " $\mathrm{c}(2)$ " on a "without recourse" basis from other banks and financial institutions; ${ }^{22}$ or

(iv) Purchase/discount on a "with or without recourse" basis of MSE receivables, other than BMBE receivables which are covered in Item "c(3)" hereof; or

(v) Wholesale lending or rediscounting facility granted to participating financial institutions (PFIs) for on-lending to MSEs, other than to BMBEs which are covered in Item "c(3)" hereof; or

(vi) Wholesale lending or rediscounting facility granted to PFIs for on-lending to export, import, and domestic micro and small scale traders, other than to BMBEs which are covered in Item "c(3)" hereof; or

(vii) Commercial letters of credit outstanding, net of margin deposits, issued for the account of MSEs.

\footnotetext{
${ }^{21}$ Item c(3) under subsection X342.3 (Eligible credit exposures) of the BSP Manual of Regulations for Bank (MORB) 2008 stipulates the mechanisms considered as "Alternative compliance for either or both MSEs or/and MEs." The provision classifies "Loans from whatever sources granted to BMBEs as provided under Subsection X365.5" as a form of alternative compliance. Section 365 of MORB 2008 covers regulations concerning "Loans to Barangay Micro Business Enterprises" while subsection $X 365.5$ pertains to the "Incentives to participating financial institutions."

22 Items c(1) and c(2) under subsection X342.3 of the MORB 2008 are as follows: (1) Paid subscription/purchase of liability instruments as may be offered by the SB Corporation; (2) Paid subscription of preferred shares of stock of the SB Corporation.
} 
For medium enterprises:

(i) Actual extension of loans to eligible MEs provided that loans granted to MEs to the extent funded by wholesale lending of, or rediscounted with, another bank shall not be eligible as compliance with the mandatory credit allocation; or

(ii) Loans granted to export, import, and domestic medium scale traders provided that loans granted to MEs to the extent funded by wholesale lending of, or rediscounted with, another bank shall not be eligible as compliance with the mandatory credit allocation; or

(iii) Purchase of eligible ME loans listed in items "i" and "ii" of this list on a "without recourse" basis from other banks and financial institutions; or

(iv) Purchase/discount on a "with or without recourse" basis of ME receivables; or

(v) Wholesale lending or rediscounting facility granted to PFIs for on-lending to MEs; or

(vi) Wholesale lending or rediscounting facility granted to PFIs for on-lending to export, import, and domestic medium scale traders; or

(vii) Commercial letters of credit outstanding, net of margin deposits, issued for the account of MEs.

\section{B. Alternative Compliance}

Acknowledging the difficulty and the risks of lending to fledgling enterprises early on, the government has established a set of alternative vehicles in order to comply with the MSME lending provisions of the Magna Carta.

Alternative compliance for either or both MSEs or/and MEs are allowed on the following grounds: first through paid subscription or purchase of liability instruments offered by the SBC, through paid subscription of preferred shares of stock of the SBC, or through loans (irrespective of sources) granted to Barangay Microbusiness Enterprises. ${ }^{23}$

Earlier, banks can also set aside special accounts consisting of cash or "due from BSP" for MSMEs which are free, unencumbered, not hypothecated, not utilized or earmarked for other purposes and include the corresponding amounts to their compliance reports as per BSP Circular 147 (1997). But this was no longer included as a mode of compliance under the new Magna Carta (RA 9501) beginning from 2008.

\section{Penalty for Noncompliance}

In case of noncompliance, the current penalty is relatively lenient compared with the previous versions of Magna Carta law. Under initial versions of the law, noncompliant banks are fined by an amount no less than P500,000 and other officers of the erring lending institutions shall be individually liable for imprisonment of not less than 6 months. ${ }^{24}$ The subsequent revision of the law in 1997 extended the loan earmarking program for SMEs to 2007, and dropped imprisonment provision while maintaining the monetary fine (Table 5). ${ }^{25}$

The monetary penalty for noncompliance varied according to bank types though the amount was miniscule compared to the average banking assets of these institutions. Based on the most recent

23 See BSP Circular No. 625 dated 14 October 2008. Subsection X365.5 of circular explains fully the details of this item.

24 RA 6977 (Small Enterprises Magna Carta of 1991) for more details.

25 RA 8289 (SME Magna Carta of 1997). 
revision in 2008 , banks were mandated to allocate $2 \%$ of their loan portfolio to medium enterprises, and $8 \%$ to micro and small enterprises. Yet banks were fined a mere $\$ 2,300$ for every percentage point that the banks failed to meet the stipulated medium enterprises loan share, and a mere $\$ 9,300$ for every percentage point below the stipulated micro and small enterprises share of the banks' loan portfolio. The penalty for other noncompliant reporting behaviors was even smaller-the daily fines for the delay in submitting compliant reports range from a mere $\$ 2$ for rural and cooperative banks to $\$ 28$ for universal and commercial banks (Table 9).

Table 9: Penalty Matrix

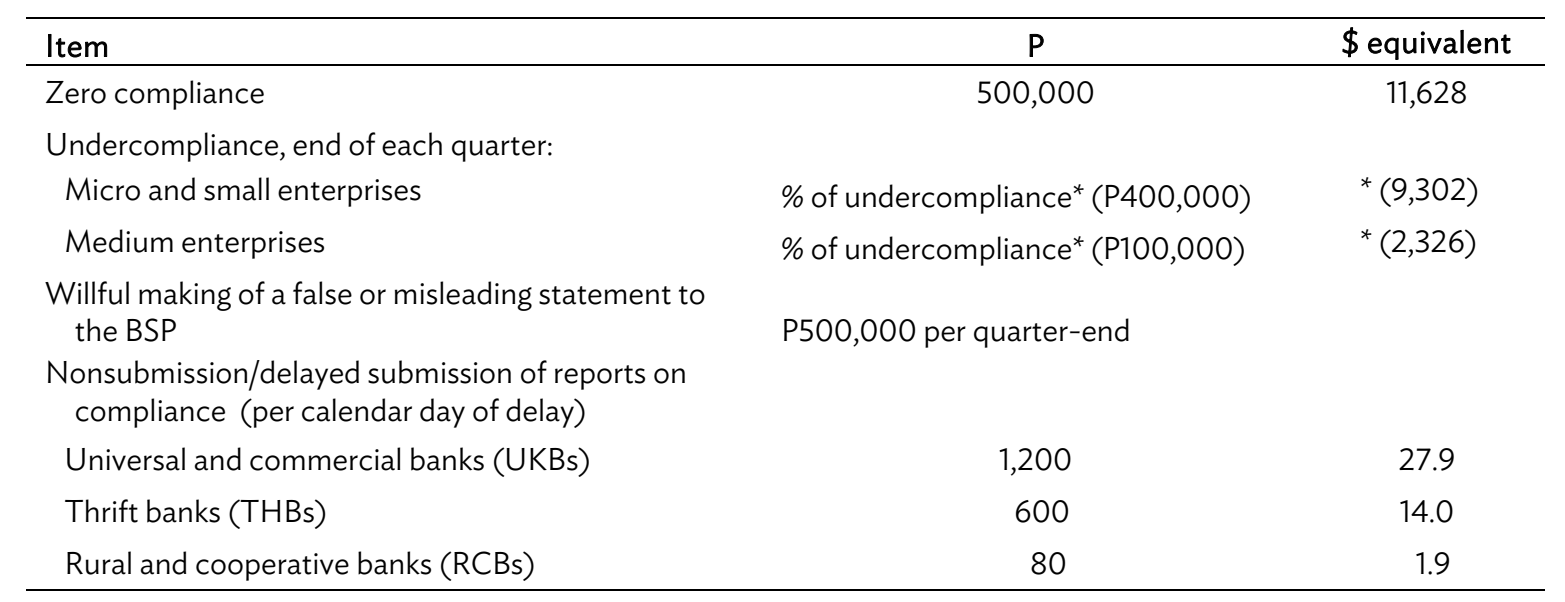

Note: $\mathrm{P} / \$=43$.

Source: Republic Act 9501.

One interesting feature of the law is the provision for aggregated group compliance. BSP Circular 625 (2008) states that "banks may be allowed to report compliance on a groupwide (i.e., consolidation of parent and subsidiary bank/s) basis so that excess compliance of any bank in the group can be used as compliance for any deficient bank in the group on the following conditions: (a) provided that the subsidiary bank/s is/are at least majority-owned by the parent bank and (b) provided further that the parent bank shall be held responsible for the compliance of the group."

\section{ASSESSING BANK COMPLIANCE TO THE MICRO, SMALL, AND MEDIUM ENTERPRISE MAGNA CARTA}

Given the low levels of penalty meted out to those who did not comply with the MSME Magna Carta, it is interesting to assess actual bank compliance to the law. This section intends to shed light on the levels and trends of bank lending to MSMEs in the Philippines and to assess banks' compliance to the Magna Carta. We proceed in two steps. First we provide an industry-level analysis, which examines the overall aggregate MSMEs lending activity of banks as a group. Second we use bank-level data to analyze patterns of compliance to the Magna Carta for MSMEs by individual universal and commercial banks, and thrift banks.

\section{A. Data Sources}

For the industry aggregate-level analysis, we used the data on banking industry's lending to MSMEs provided by the BSP. The data series present information about the compliance to the Magna Carta for 
MSMEs of the three major bank types (UKBs, thrifts, and rural co-ops) covering the years from 1999 to 2010. Moreover, the data show the disaggregation of the MSME compliance to the Magna Carta according to type of compliance; in other words, we know whether the banks complied through direct compliance, indirect compliance, or "funds set aside for MSMEs." ${ }^{26}$ However, as mentioned earlier, funds set aside for MSMEs are no longer considered as mode of compliance beginning 2008.

To assess compliance at the bank-level, we compiled a comprehensive panel dataset from the Published Statements of Condition of each lending institution posted on the BSP's website. The data series covers periods from the first quarter of 2005 to the second quarter of 2011 but limited to UKBs and thrifts because the BSP does not post the compliance information for individual rural co-ops. While these published statements comprised the most complete data publicly available on the compliance patterns of financial institutions, we note two caveats pertaining to the quality of data. Firstly, the format of the compliance ratios in these published statements (i.e., whether in percentage or absolute terms) is not consistent across reports. Some information do not appear meaningful (e.g., compliance ratios that are over 100\%). Thus, caution was exercised in building the panel dataset of compliance ratios. Secondly, a number of banks do not report their Magna Carta compliance ratios in some of their public statements. Hence, we need to distinguish zero lending to MSMEs from absence of data. The summary statistics are given in Tables 1 and 2 in the Appendix. Nevertheless, our postcleaning final sample with complete data consists of 109 financial institutions (out of an initial sample of 136), which altogether represented over $90 \%$ of the finance sector assets in the Philippines.

\section{B. Descriptive Statistics of Aggregate Lending}

The outstanding amount lent by all lending institutions to MSMEs increased modestly from 1990 to 2010 (Figure 1). Financing to MSMEs rose from P248.2 billion to P308.5 billion in those 12 years, representing a growth rate of roughly $24.3 \%$ during the period or $2.32 \%$ per year growth. UKBs provide the lion's share of the loan provisions, accounting for $72.9 \%$ of the total credit lines in 2010 (which is a decrease from their market share of $83.7 \%$ in 1999). THBs, on the other hand, saw their share of MSME lending rising from 13\% in 1999 to 19.8\% in 2010. The strongest growth in market share is observed for RCBs, which tripled their share of MSME financing from below 3.3\% in 1999 to12.6\% in 2009, before retreating to just above $7.3 \%$ by the end of 2010 .

The decline in UKBs' market share is brought about by the tepid growth in its lending operations between 1999 and 2010, which saw a compounded annual growth rate of only 0.72\%. Thrifts, on their part, were more aggressive in attending to MSMEs capital needs, registering $7 \%$ average loan growth during the 11-year span. Meanwhile, RCBs have been the most aggressive in capturing MSMEs' credit demands, growing its exposure by $20 \%$ annually until 2008 until a pullback beginning in 2009. In 2009, total MSME lending by rural co-ops declined by $1.4 \%$, and then contracted sharply in 2010 by $41.9 \%{ }^{27}$

Between 1990 and 2010, the growth in MSME lending could be (almost) entirely attributed to the growth in lending to medium enterprises (Figure 2). Outstanding loans to medium enterprises increased by almost 50\% from P100.1 billion in 1999 to P149.4 billion in 2010

26 The "funds set aside for MSMEs" is defined by the BSP (as indicated in the data file) as the item consisting of either Cash on Hand and Due from BSP which are free, unencumbered, not hypothecated, not utilized or earmarked for other purposes. The Due from BSP is a special account deposited with the BSP and does not form part of the bank's legal reserves. Under the new mandatory credit allocation (RA 9501).

27 The compounded annual growth rate of MSME lending for thrifts was $6 \%$. In contrast, the compounded annual growth rate for RCBs was $19.3 \%$ from 1998 to 2008 and fell to $9.8 \%$ by the end of 2010 . 
(representing a CAGR of 3.7\%). UKBs provided approximately slightly $80 \%$ of total loans to medium enterprises during this period. By 2010, thrifts accounted for $14.8 \%$ of MSME bank loans whereas rural co-ops only provided $3.9 \%$ of the bank credit obtained by medium-sized enterprises.

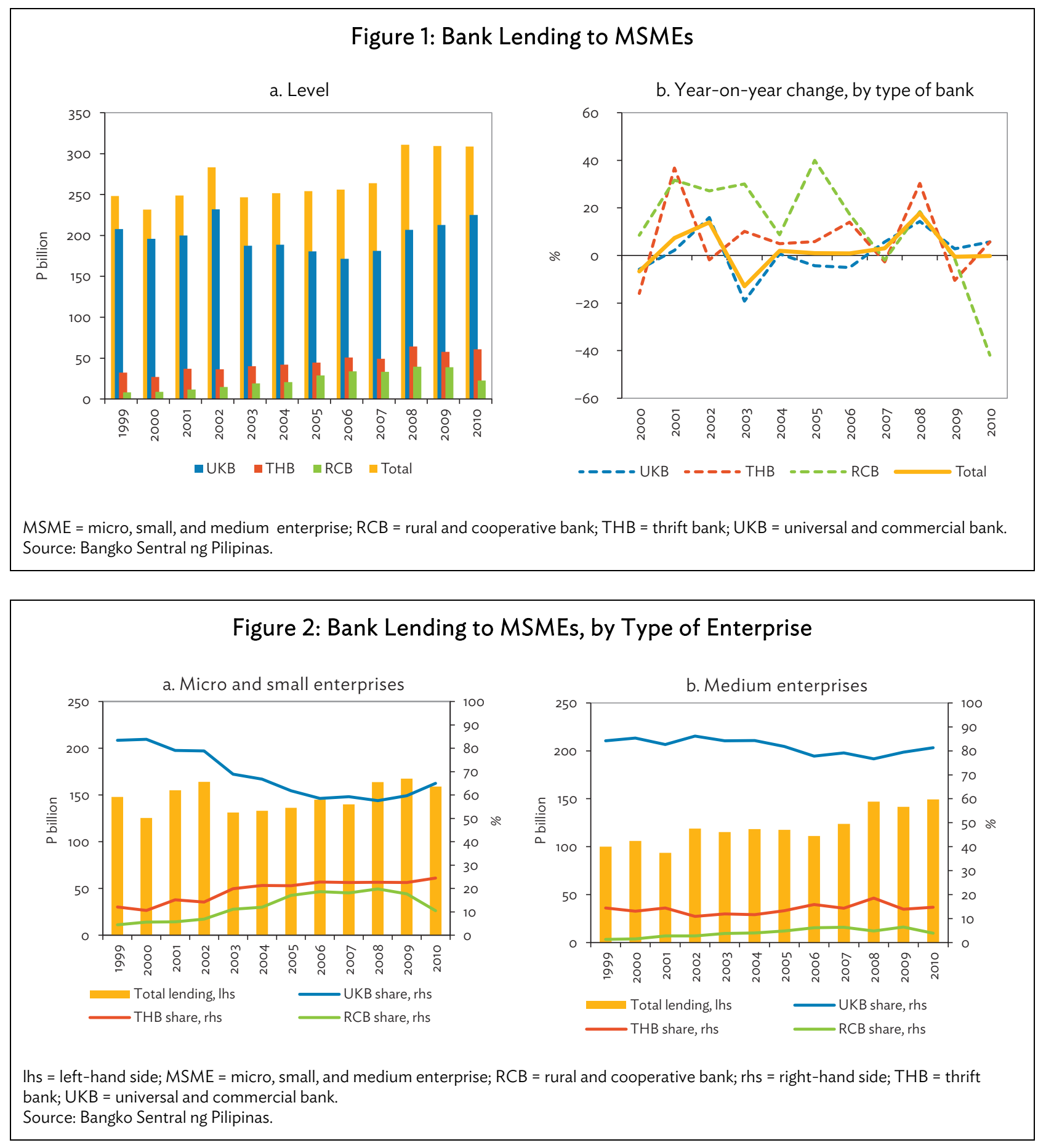

On the other hand, outstanding loans to micro and small enterprises practically plateaued since 1999 with an annual compounded growth rate of only $0.66 \%$. Again, UKBs dominated aggregate lending to micro and small enterprises. But its market share has decreased from $83.5 \%$ in 1999 to $65 \%$ 
in 2010. Thrifts were the major gainers of UKBs' lost ground, increasing their share to $24.5 \%$ in 2010 from $12 \% 11$ years earlier. Rural co-ops have also increased their market share, from only $4.5 \%$ in 1999 to $19.8 \%$ by the end of 2008 . Nevertheless, due to the contraction in their lending in 2010 , their market share slipped to just $10.5 \%$ by the end of 2010 .

Though the recent trends favor larger firms, historically the majority of MSME loans has gone toward micro and small firms. Nevertheless, there are significant differences between the portfolio allocations of various banking groups. For UKBs, loans to medium firms overtake smaller ones beginning in 2003. They increased their lending to medium firms from P84.2 billion in 1999 to P121.5 billion in 2010 (compounded growth rate of 3.4\%), while reducing their loans to micro and small firms from P123.6 billion to P103.4 billion (compounded growth rate of $-1.6 \%$ ) within the same time period (Figure 3).

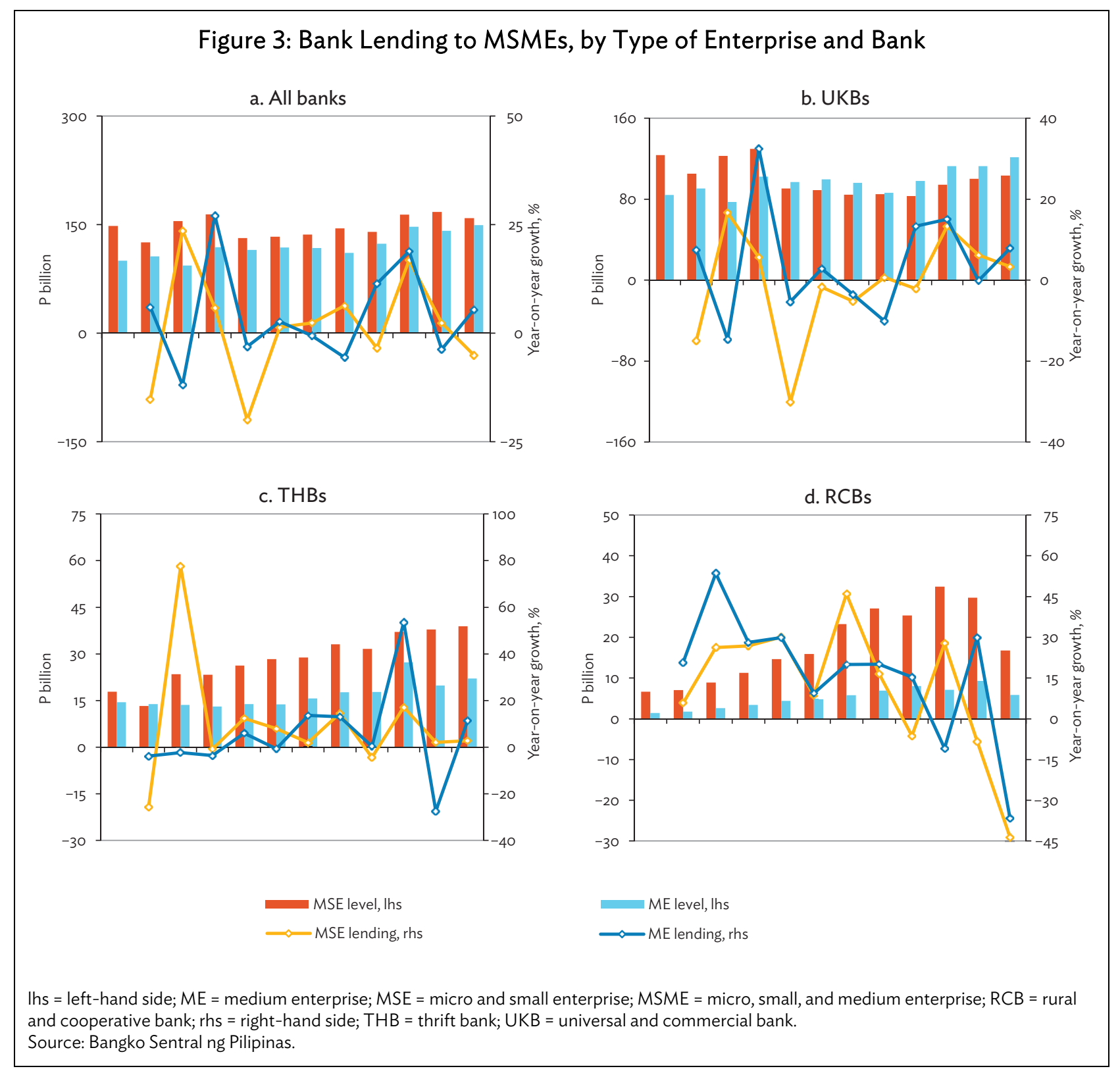


In contrast, micro and small firms still account for the majority of MSME loans for thrifts and rural co-ops. Thrifts increased their loans to both segments of the MSMEs during the period: increasing lending to micro and small firms from P17.8 billion to P38.9 billion (compounded growth rate of 7.4\%) and that to medium firms from P84.2 billion to P121.5 billion (compounded growth rate of 3.9\%). Among the various lending institutions, rural co-ops' lending to MSMEs grew the most. Their loans to micro and small firms increased fivefold from P6.6 billion in 1999 to P32.4 billion in 2008, although it was halved in the next 2 years to P16.8 billion. Similarly, their loans to medium firms increased more than sevenfold from P1.4 billion in 199 to P9.3 billion in 2009, before scaling back to P5.9 billion. Thus, in spite of the sharp downturns between 2009 and 2010, the rural co-ops still registered a strong 11.3\% annual growth rate in their lending to micro and small enterprises and an average lending growth rate of $16.3 \%$ for medium enterprises throughout the 11 -year period.

\section{Aggregate Direct Lending to Micro, Small, and Medium Enterprises}

The aggregate data reveals two important trends. Firstly, despite the increase in total lending volume, the share of MSMEs in the banking sector's lending portfolio has declined significantly since 2002. Secondly, despite the decreasing share in MSME loans, aggregate lending to the MSME sector still far exceeds the explicit 10\% goal of the Magna Carta. At the peak in 2002, MSMEs accounted for $30 \%$ of the total loan portfolio of all lending institutions. This declined to $16.4 \%$ in 2010 (Figure 4). The reduction in banks' MSME exposure is common across banking groups. Thrifts have started moving away from the MSME market in 2000. The UKBs followed a similar track in 2002. And even the rural co-ops began expanding more in non-MSME market in 2006. Between their respective peak years (i.e., years when MSMEs' share in banks' lending basket is at its highest) and 2010, MSMEs' share of total lending dropped dramatically. ${ }^{28}$ UKBs reduced MSMEs' share in their portfolio by 14.8 percentage points. Thrifts reduced theirs by 30.6 percentage points. Rural co-ops, which were focused on the MSME sector, reduced their share the most, decreasing MSME lending by 23.8 percentage points (from $70.6 \%$ of their total loan portfolio down to $46.3 \%$ ).

It is important to point out that despite the decline, lending to medium firms in 2010 was more than $300 \%$ above the Magna Carta target of $2 \%$, while that for micro and small firms were closer to the targeted $8 \%$ of total bank lending. Not so surprisingly, the reduction affected smaller firms more than medium firms (Figure 4). What is intriguing is that in 2010, the bank lending to medium firms, despite declining from a peak of $12.6 \%$ of all loans, was still more than threefold of the relevant Magna Carta target. Meanwhile, lending to the micro and small segment was closer to the mandatory requirement of $8 \%$. This is mainly driven by the continuous decline of UKB lending to medium-sized enterprises-which in itself is already 1.4 percentage points below the legal requirement in 2010. Thrifts and rural co-ops, on the other hand, still keep their ratios above what is mandated by the Magna Carta but the pace at which these ratios are decreasing raises the question of the future trends for loans to micro and small firms. These trends imply that although absolute levels of lending to MSMEs are rising, the growth rates of lending to the said target sectors are consistently slower than the growth of bank lending to other sectors.

28 These periods are as follows: 2000 for THBs (54.3\%), 2002 for UKBs (29.1\%), and 2006 for RCBs (70.1\%). 
Figure 4: Bank Lending to MSMEs, by Type of Bank

(\% of loan portfolio)

a. All banks

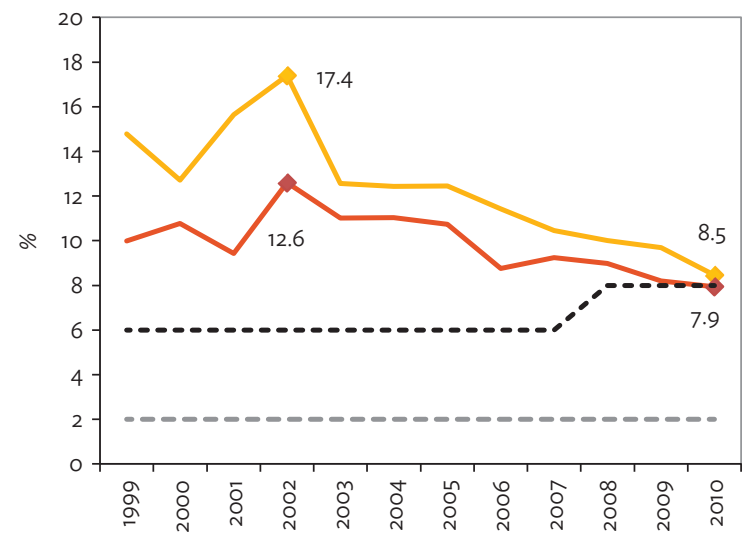

c. THBs

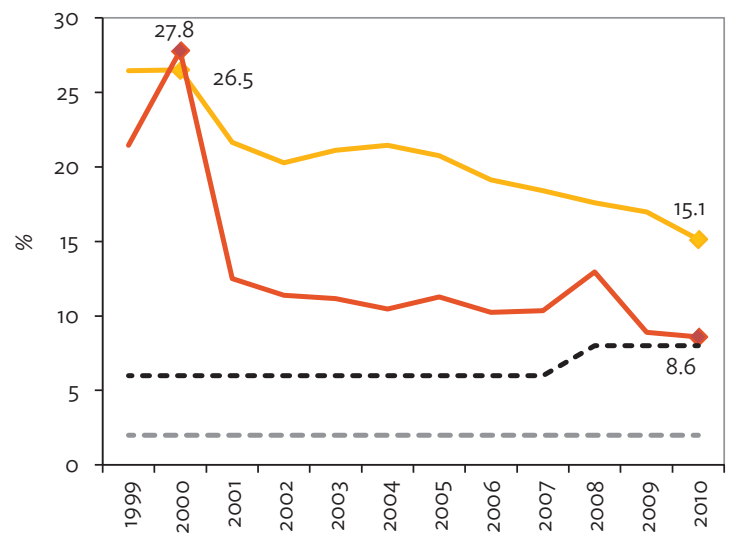

b. UKBs

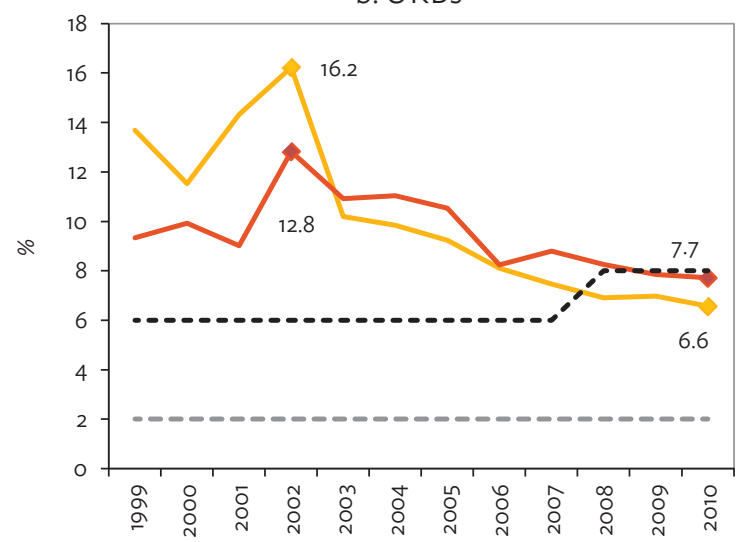

d. RCBs

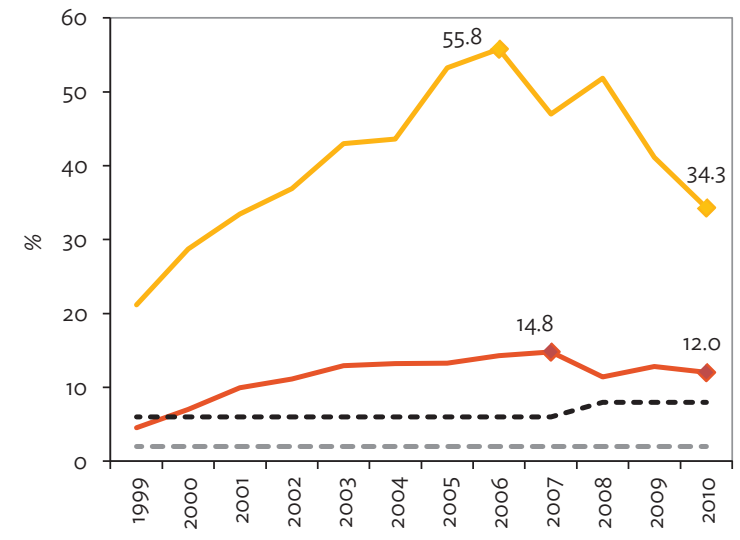

MSE loans ratio $\quad$ ME loans ratio

-.-.-. MSE benchmark _. - - ME benchmark

$M E$ = medium enterprise $M S E=$ micro and small enterprise MSME = micro, small, and medium enterprise; $R C B=$ rural and cooperative bank; THB = thrift bank; UKB = universal and commercial bank.

Note: Total loan portfolio is net of certain exclusions per BSP Circular 625 (2008).

Source: Bangko Sentral ng Pilipinas.

\section{Direct Compliance versus Alternative Compliance}

As can be gleaned from Figure 5, banks have been favoring direct compliance since 1999 and even more so since 2008. Data provided by the central bank indicate that banks have actually reduced exposure to other facilities and instead increased direct lending operations since 2008 to almost $100 \%$ of their lending to MSMEs. The lack of attractiveness of the yields of alternative notes appears to be one of the key issues. Lamberte (2002) observes that alternative modes of compliance like SBC notes "do not pay market rates" while deposits with the central bank allotted for SMEs do not bear interest. SBC's wholesale lending also took a hit during the height of the global financial crisis when the central bank expanded and reduced the interest rate of its rediscounting facility to keep the banking system liquid, "which directly competed with SB Corporation's wholesale lending operations," (ADB 2010). 
Figure 5: Distribution of Direct and Indirect Lending to MSMEs, by Type of Bank (\% of total compliance)
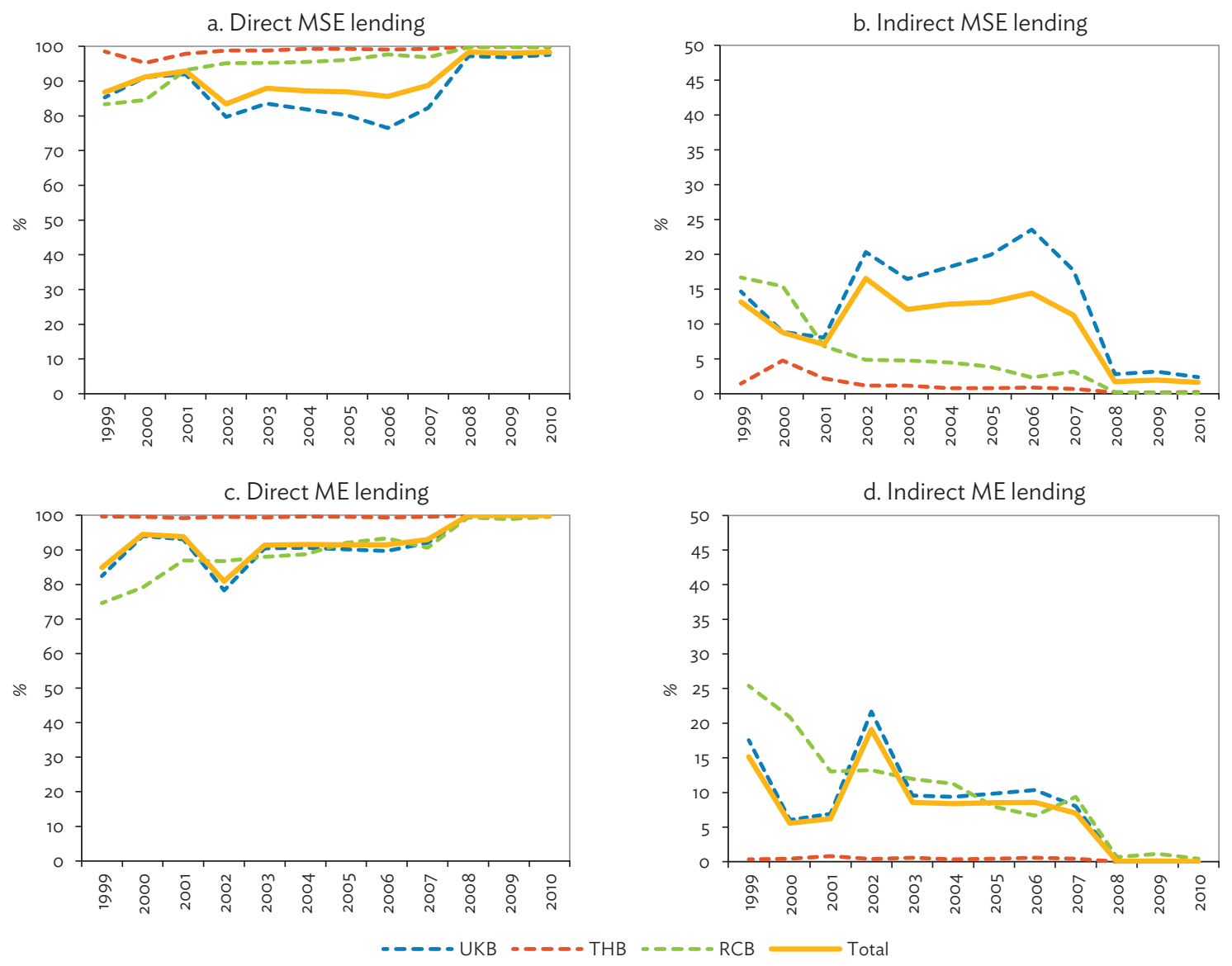

$\mathrm{ME}=$ medium enterprise; $\mathrm{MSE}=$ micro and small enterprise; $\mathrm{MSME}=$ micro, small, and medium enterprise; $\mathrm{RCB}=$ rural and cooperative bank; THB = thrift bank; UKB = universal and commercial bank.

Note: Indirect compliance includes "Funds Set Aside for MSMEs" for the years 1999-2007.

Source: Bangko Sentral ng Pilipinas.

In response, the SBC, through Memorandum No. 6 (2011), has decided to narrow the spread of its notes against the benchmark secondary bond rate (PDST-F) from $33 \%$ of the yields of the corresponding reference fixed-income notes (1 year and 6 months) to $20 \%{ }^{29}$ SBC also issued preferred shares worth P1.6 billion at P100 per share (minimum of 2,000 shares) to further boost its capital. But whether these moves could entice more capital remains to be seen. Notably, the ADB loan granted to SBC has been the corporation's biggest infusion of rolling capital between 2000 and 2010. In 2005 the loan accounted for $11 \%$ of the corporation's total lending in $2006,51 \%$ in $2007,61 \%$ in 2008 , and $76 \%$ in the first half of 2009 (ADB 2010).

\section{E. Bank-Level Data and Descriptive Statistics}

Overall, we find that the aggregate loans to MSMEs were greater than targeted by the Magna Carta, and especially robust for loans to medium firms. Nonetheless, aggregate trends are silent on the

29 This secondary bond rate is also referred to as the Money Market Association of the Philippines (MART 1) benchmark rate. 
patterns of individual compliance to the law. This section examines individual bank compliance to the Magna Carta for MSMEs, using comprehensive panel data that we have compiled. This is, as far as we are aware, the first panel data and analysis on this question. Data on these individual lending institutions were available quarterly from 2005 to 2011, and did not cover rural and cooperative banks.

\section{General trends of direct compliance by lending institutions}

Data from individual lending institutions reveals significant heterogeneity in the direct compliance of various lending institutions to the law. In particular, there was a decrease in direct compliance amongst universal and commercial banks beginning in the late 2007. Based on the published statements of conditions disclosed by the BSP, approximately $33 \%$ of all the UKBs reporting data to the BSP were lending less than $8 \%$ of their total loan to micro and small enterprises by 2011. Another $10 \%$ of all UKBs also did not meet the $2 \%$ of loan portfolio mandatory lending requirement to medium enterprises (Figure 6).

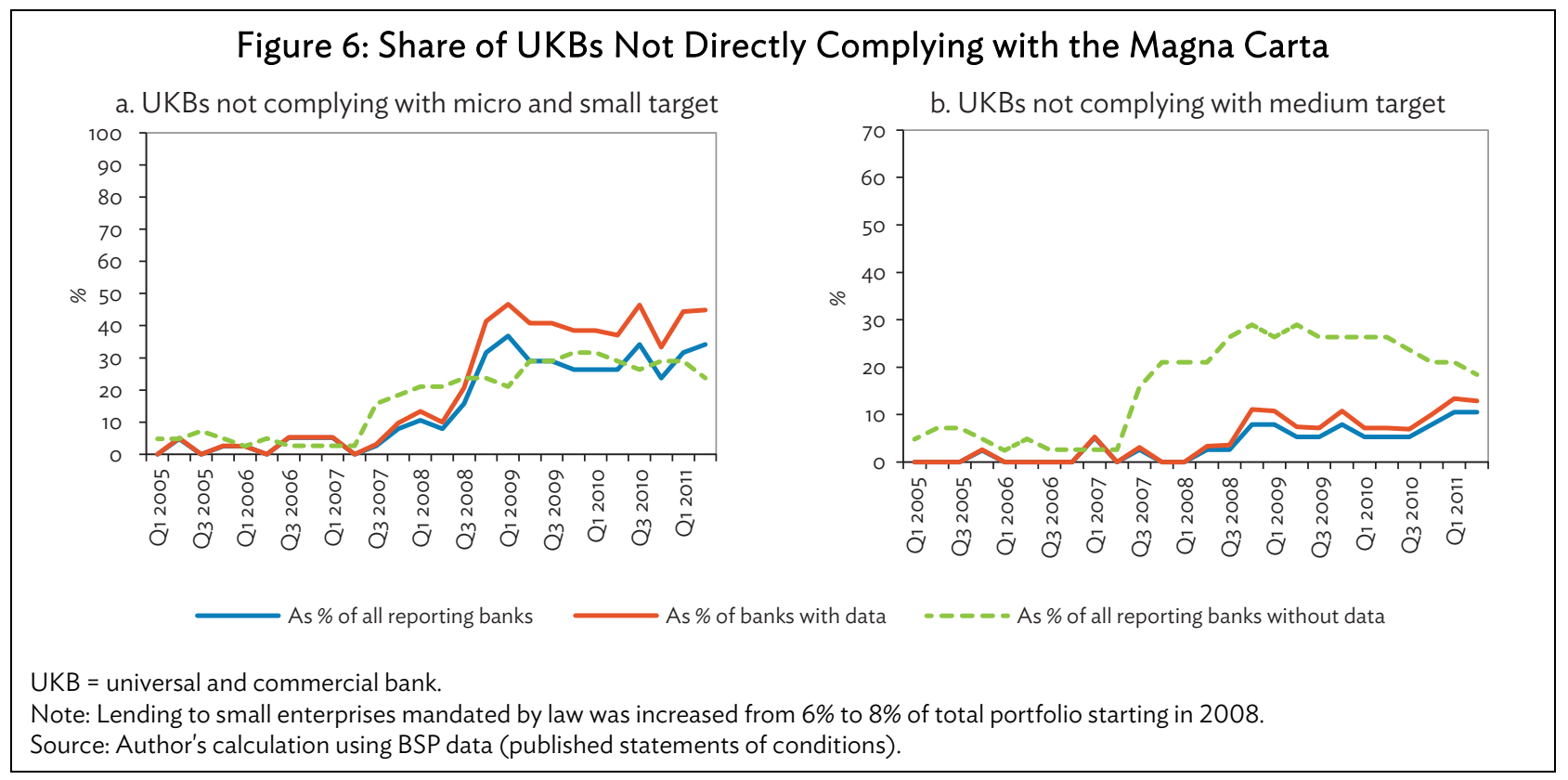

This was a stark contrast to the earlier years, when direct compliance was much stronger (in other words, direct noncompliance was almost zero). In 2005, noncompliant UKBs were only about $5 \%$ (small) and 5.3\% (medium) of the group. Moreover, about a quarter of the supervised banks has not indicated their MSME lending ratios in their reports. Approximately three quarters of these banks with no data are foreign-owned. Based on the available information on loan portfolios of foreignowned banks, it is possible that the actual noncompliance among UKBs could exceed $60 \%$ for micro and small, and around $25 \%$ for medium enterprises. ${ }^{30}$

One of the reasons the sharp decrease in direct compliance could be the increase in the mandated MSME loan share from $6 \%$ to $8 \%$ following the revision of the law in 2008. It is possible that many UKBs found it challenging to increase their loans to micro and small enterprises by another 2 percentage points when the regulation was altered. Even though microenterprises were added into the equation, this proved

30 In a separate study, SBC also estimated that $60 \%$ of UKBs are not complying with the mandated MSE portfolio while $32 \%$ of UKBs are not complying with the mandated ME portfolio (See Lagua 2011). 
to be of little value to them since microenterprises were not the focus of most UKBs. Unfortunately the data does not disaggregate loans to small and microenterprises. As for UKBs' declining share of loans to medium firms, one potential explanation could be the uncertainties of the economic conditions that affected the country's external position following the global financial crisis of 2008.

On the other hand, direct compliance among thrift banks has increased from $86 \%$ in 2005 to almost $97 \%$ as of the first quarter of 2011 (Figure 7). Although it appears that the revision in the Magna Carta compounded by the sudden downturn in the general business climate has affected the UKBs lending to MSMEs adversely, these factors seem to have muted effect on thrift banks. Perhaps, the policy change may have even benefited them since thrift banks (together with rural and cooperative banks) have better access to microenterprises than the universal banks. Hence, the inclusion of microenterprises in the mandated lending requirement has most likely allowed some of these thrift banks that are formerly below the benchmark to meet the legal requirement in spite of the 2 percentage point increase in the legal threshold.

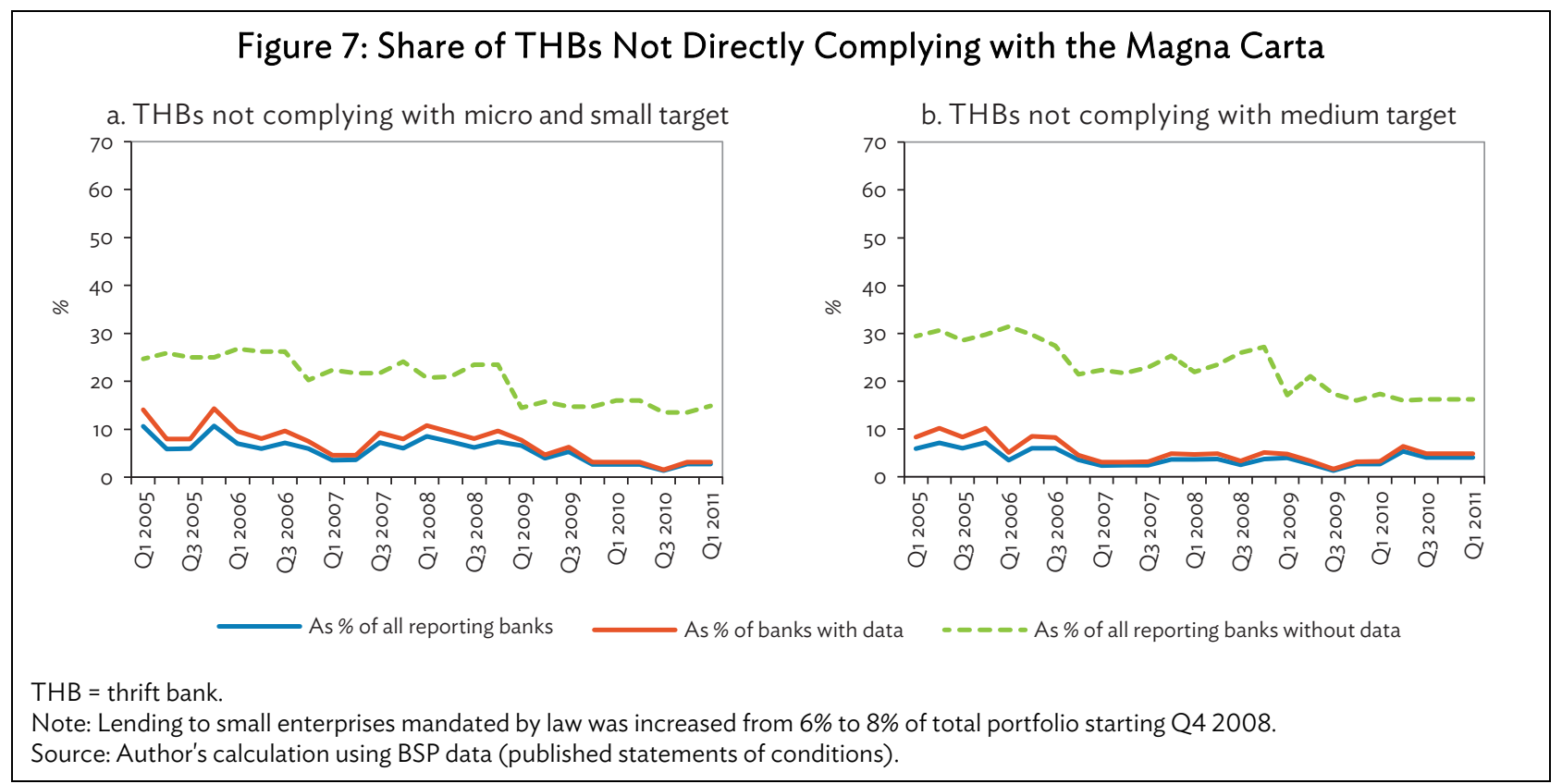

\section{Robustness of direct compliance from 2005 to 2010}

In order to better compare compliance to the Magna Carta for MSMEs across individual banks from 2005 to 2010, we conduct robustness checks and truncate the sample size in order to address reporting errors. We identified 136 banks for which quarterly balance sheet information are provided over the period of study, 130 of which reported their lending ratios. We correct for outliers by removing bank-quarter observations where the compliance ratios are below the 1st percentile and above the 99th percentile values. Next, we exclude banks with less than 8 quarters of time series observations. These restrictions enable us to focus on banks with sufficient data on compliance ratios while dropping banks that were previously merged, acquired and bankrupt. Our final sample consists of 109 banks, which altogether represent over $90 \%$ of the assets of all universal, commercial, and thrift banks over the period. 
We also define four indicators to measure the degree of banks' compliance to the Magna Carta Law. UNDERCOMPLY is a dummy variable that takes the value 1 if the bank's lending to the MSME segment for each quarter is less than the mandatory bank lending requirement. This legal mandate is $6 \%$ for small firms until Q2 2008, and 8\%, thereafter; and 2\% for medium-sized firms. JUSTCOMPLY is a dummy variable that is equal to 1 if the bank's lending ratio falls within 100 to $110 \%$ of the target. OVERCOMPLY takes the value of 1 if the lending share ranges from $110 \%$ to $200 \%$ of the target. SUPERCOMPLY is a dummy variable that takes the value 1 if the loan share for the segment exceeds the respective target by $200 \%$.

Just as the aggregated data has highlighted, the average loan shares of both micro and small enterprises and medium enterprises were far higher than the legal targets of $6 \%$ and $2 \%$ respectively (Table 10). On average, the banks in this truncated sample increased the share of micro and small enterprises loans within their portfolio from an average of 15.8\% in 2005 to $17.5 \%$ in 2010. Thus the average lending institution (out of 130) was lending 3 times the targeted share for small and medium enterprises. However, loans to medium firms were only slightly higher than targeted: in 2010, the average bank lent $10 \%$ of their portfolio to medium firms.

Nonetheless, there is considerable dispersion in banks' decisions to lend to MSMEs. Although universal and commercial banks supplied the biggest amount of loans to MSMEs, their own loan portfolio reflected that lending to MSMEs were not their priorities. For these banks, the share of micro and small firms in their loan portfolios ranged from $1.7 \%$ to $25.4 \%$ in 2010 , while the share of medium firms ranged from $0.1 \%$ to $24.9 \%$. It is noteworthy that the average UKB reported only $7.7 \%$ of loans to micro and small enterprises, which is below the Magna Carta target.

Meanwhile, there is even greater dispersion in the portfolio decisions of the smaller thrift banks although on average they greatly exceeded the Magna Carta targets. The average thrift bank allotted $21.8 \%$ of its loans to micro and small firms (almost 3 times the target), and another $11 \%$ to medium firms (over 5 times the target). This suggests that on average, the focus of thrift banks was indeed the smaller firms. ${ }^{31}$ Nevertheless, the share of loans to micro and small firms ranged from $1.1 \%$ to $88.2 \%$, while that of medium firms ranged from $0.2 \%$ to $62.4 \%$. Clearly, some thrift banks were focusing on micro and small firms, while some focused on larger firms.

The trends from individual banks reporting data can be summarized in the following three points. First, universal and commercial banks tend to not focus on MSMEs though they supplied the bulk of credits to MSMEs. Second, loans to medium firms were much higher than legally mandated across all banks. Third, there was a huge dispersion across banks in their optimal loan portfolio choices.

How many banks were directly complying with the Magna Carta Law? Our panel dataset on compliances included 24 quarters of data that can shed some light on the dispersion in portfolio choices (Table 11). We find that only $65.4 \%$ of all banks were complying directly on the target for micro and small enterprises at least one quarter. In other words, $36.4 \%$ of banks reported at least one incident of undercompliance. Only $2.1 \%$ of all banks reported undercomplying with the target of direct lending to the micro and small enterprises for 13 to 16 quarters (more than half of all the periods observed). Another 5.5\% of banks reported undercomplying between 9 and 12 quarters. More importantly, the majority of banks reported overcomplying (and even supercomplying) with the micro

31 Interestingly, the share of medium firms in the average thrift bank loan portfolio has decreased from $14 \%$ in 2005 to $11 \%$ in 2010. 
and small lending targets for at least one quarter. In fact $8.4 \%$ of all banks reported that they supercomplied for most of the periods observed.

Table 10: Summary Statistics of MSME Lending According to Firm Size and Bank Type across Time, 2005-2010

\begin{tabular}{|c|c|c|c|c|c|c|c|}
\hline & 2005 & 2006 & 2007 & 2008 & 2009 & 2010 & ALL \\
\hline & \multicolumn{7}{|c|}{$\%$ of loans to micro and small: Whole sample } \\
\hline Mean & 15.8 & 16.07 & 17.31 & 16.51 & 15.79 & 17.49 & 16.64 \\
\hline Std Dev & 14.44 & 15.29 & 16.73 & 14.99 & 14.8 & 15.6 & 25.34 \\
\hline Min & 0.95 & 0.59 & 1 & 0.77 & 0.55 & 1.12 & 0.55 \\
\hline \multirow[t]{2}{*}{ Max } & 87.99 & 75.57 & 84.56 & 87 & 88.31 & 88.18 & 88.31 \\
\hline & \multicolumn{7}{|c|}{$\%$ of loans to medium: Whole sample } \\
\hline Mean & 11.12 & 10.63 & 11.7 & 11.7 & 10.32 & 10.01 & 10.92 \\
\hline Std Dev & 11.4 & 11.06 & 12.68 & 11.05 & 9.08 & 9.56 & 10.91 \\
\hline Min & 0.53 & 0.22 & 0.09 & 0.15 & 0.1 & 0.12 & 0.09 \\
\hline \multirow[t]{2}{*}{ Max } & 61.83 & 59.04 & 63.5 & 62.45 & 54.01 & 62.39 & 63.5 \\
\hline & \multicolumn{7}{|c|}{$\%$ of loans to micro and small: UKB } \\
\hline Mean & 8.16 & 7.54 & 7.57 & 7.78 & 7.66 & 7.66 & 7.73 \\
\hline Std Dev & 3.8 & 3.19 & 3.45 & 3.17 & 2.95 & 3.1 & 3.31 \\
\hline Min & 5.27 & 5 & 4.75 & 1.79 & 1.97 & 1.74 & 1.74 \\
\hline \multirow[t]{2}{*}{ Max } & 30.05 & 23.83 & 27.34 & 22.63 & 15.73 & 21.54 & 30.05 \\
\hline & \multicolumn{7}{|c|}{$\%$ of loans to medium: UKB } \\
\hline Mean & 7.13 & 6.35 & 6.49 & 7.53 & 7.43 & 7.86 & 7.06 \\
\hline Std Dev & 5.25 & 4.51 & 4.57 & 4.83 & 4.18 & 5.12 & 4.78 \\
\hline Min & 1.98 & 2 & 1.64 & 0.15 & 0.1 & 0.12 & 0.1 \\
\hline \multirow[t]{2}{*}{ Max } & 24.93 & 20.98 & 21.85 & 19.39 & 17.18 & 24.53 & 24.93 \\
\hline & \multicolumn{7}{|c|}{$\%$ of loans to micro and small: Thrift banks } \\
\hline Mean & 20.78 & 21.31 & 22.61 & 20.52 & 20.71 & 21.81 & 27.3 \\
\hline Std Dev & 16.51 & 17.29 & 18.61 & 16.5 & 16.07 & 16.94 & 17.01 \\
\hline Min & 0.95 & 0.59 & 1 & 0.79 & 0.55 & 1.12 & 0.55 \\
\hline \multirow[t]{2}{*}{ Max } & 87.99 & 75.57 & 84.56 & 87 & 88.31 & 88.18 & 88.31 \\
\hline & \multicolumn{7}{|c|}{$\%$ of loans to medium: Thrift banks } \\
\hline Mean & 13.93 & 13.32 & 14.65 & 13.66 & 11.54 & 10.98 & 12.99 \\
\hline Std Dev & 13.54 & 12.96 & 14.7 & 12.52 & 10.24 & 10.86 & 12.58 \\
\hline Min & 0.53 & 0.22 & 0.09 & 0.2 & 0.31 & 0.26 & 0.09 \\
\hline Max & 61.83 & 59.04 & 63.5 & 62.45 & 54.01 & 62.39 & 63.5 \\
\hline
\end{tabular}

MSME = micro, small, and medium enterprise; UKB = universal and commercial bank.

Source: Authors' calculations using data from the ADB SME Financing Survey.

Not surprisingly, banks were better able to comply with the legal targets for medium enterprise loans. Most banks (69.2\%) reported supercomplying at least for one quarter by lending more than twice the legal mandate to medium firms. Only 15\% of all banks reported any incidence of undercompliance. Furthermore, only $3.5 \%$ of all banks reported that they failed to comply with the medium-firm targets for more than 4 quarters during the period we observed. 
Table 11: Frequency of Bank Direct Compliance to the Magna Carta Targets across Bank Types in the Philippines, 2005-2010

\begin{tabular}{|c|c|c|c|c|c|c|c|}
\hline \multirow[b]{2}{*}{ Whole Sample } & \multicolumn{7}{|c|}{ Number of Quarters the Banks Complied with the Magna Carta } \\
\hline & 0 & $(1-4)$ & $(5-8)$ & $(9-12)$ & $(13-16)$ & $(17-20)$ & $(21-24)$ \\
\hline \multicolumn{8}{|c|}{ Loans to micro and small enterprises } \\
\hline UNDERCOMPLY & 65.4 & 20.1 & 6.9 & 5.5 & 2.1 & 0.0 & 0.0 \\
\hline JUSTCOMPLY & 51.6 & 22.1 & 9.7 & 11.8 & 3.5 & 1.3 & 0.0 \\
\hline OVERCOMPLY & 39.1 & 22.2 & 15.2 & 13.2 & 8.3 & 1.4 & 0.6 \\
\hline SUPERCOMPLY & 48.8 & 15.9 & 5.5 & 10.4 & 5.5 & 5.5 & 8.4 \\
\hline \multicolumn{8}{|l|}{ Medium enterprises } \\
\hline UNDERCOMPLY & 84.8 & 11.8 & 2.1 & 0.0 & 1.4 & 0.0 & 0.0 \\
\hline JUSTCOMPLY & 75.1 & 17.3 & 3.5 & 2.8 & 0.7 & 0.7 & 0.0 \\
\hline OVERCOMPLY & 55.7 & 19.4 & 14.5 & 5.5 & 3.5 & 1.4 & 0.0 \\
\hline SUPERCOMPLY & 30.8 & 10.4 & 4.8 & 10.4 & 9.7 & 8.3 & 25.6 \\
\hline \multicolumn{8}{|l|}{ UKBs } \\
\hline \multicolumn{8}{|c|}{ Loans to micro and small enterprises } \\
\hline UNDERCOMPLY & 49.2 & 26.5 & 6.6 & 13.3 & 4.4 & 0.0 & 0.0 \\
\hline JUSTCOMPLY & 18.2 & 17.7 & 22.1 & 26.5 & 11.1 & 4.4 & 0.0 \\
\hline OVERCOMPLY & 27.1 & 26.5 & 11.1 & 19.9 & 13.3 & 0.0 & 2.2 \\
\hline SUPERCOMPLY & 75.7 & 19.9 & 0.0 & 2.2 & 2.2 & 0.0 & 0.0 \\
\hline \multicolumn{8}{|l|}{ Medium enterprises } \\
\hline UNDERCOMPLY & 86.7 & 13.3 & 0.0 & 0.0 & 0.0 & 0.0 & 0.0 \\
\hline JUSTCOMPLY & 64.6 & 19.9 & 6.6 & 6.6 & 2.2 & 0.0 & 0.0 \\
\hline OVERCOMPLY & 49.2 & 15.5 & 17.7 & 8.8 & 8.8 & 0.0 & 0.0 \\
\hline SUPERCOMPLY & 29.3 & 15.5 & 6.6 & 2.2 & 6.6 & 6.6 & 33.2 \\
\hline \multicolumn{8}{|c|}{ Thrift banks } \\
\hline \multicolumn{8}{|c|}{ Loans to micro and small enterprises } \\
\hline UNDERCOMPLY & 72.8 & 17.1 & 7.1 & 2.0 & 1.0 & 0.0 & 0.0 \\
\hline JUSTCOMPLY & 66.8 & 24.2 & 4.0 & 5.0 & 0.0 & 0.0 & 0.0 \\
\hline OVERCOMPLY & 44.6 & 20.2 & 17.1 & 10.1 & 6.0 & 2.0 & 0.0 \\
\hline SUPERCOMPLY & 36.5 & 14.1 & 8.1 & 14.1 & 7.1 & 8.1 & 12.1 \\
\hline \multicolumn{8}{|l|}{ Medium enterprises } \\
\hline UNDERCOMPLY & 83.9 & 11.1 & 3.0 & 0.0 & 2.0 & 0.0 & 0.0 \\
\hline JUSTCOMPLY & 79.9 & 16.1 & 2.0 & 1.0 & 0.0 & 1.0 & 0.0 \\
\hline OVERCOMPLY & 58.7 & 21.2 & 13.1 & 4.0 & 1.0 & 2.0 & 0.0 \\
\hline SUPERCOMPLY & 31.5 & 8.1 & 4.0 & 14.1 & 11.1 & 9.1 & 22.2 \\
\hline
\end{tabular}

UKB = universal and commercial bank.

Source: Authors' calculations using data from the ADB SME Financing Survey.

\section{Distribution of direct compliance across various types of financial institutions}

In general, universal and commercial banks were less likely than thrift banks to comply with the law directly through loans rather than through alternative means For micro and small enterprise loans, almost $50 \%$ of the UKBs undercomplied for at least a quarter, compared to only $27 \%$ of thrifts. ${ }^{32}$ For some UKBs, the undercompliance was part of a long-term strategy: $17 \%$ of the UKBs have undercomplied for at least 2 years, compared to only $3 \%$ in the case of thrifts. In contrast, thrifts were more likely to supercomply: two-thirds reported supercomplying for at least one quarter, and $20.2 \%$ of

32 Overall, $72.8 \%$ of thrift banks reported zero instances of undercompliance. 
the thrifts have a long-term strategy of supercompliance by allocating at least $16 \%$ of their loan portfolio to micro and small enterprises for at least 4 years (>16 quarters). This is double the legal target. On the other hand, less than $25 \%$ of all UKBs reported any instance of supercompliance, and none consistently supercomplied for 4 years or more.

Revealed portfolio allocation of loans to medium-sized enterprises was more similar across banks. Approximately $13.3 \%$ of UKBs and $16.1 \%$ of thrifts reported at least one quarter of undercompliance. More interestingly, the supercompliance rate was higher for UKBs than thrifts. Approximately $40 \%$ of the UKBs supercomplied for at least 4 years compared with only $31 \%$ of the thrifts. This suggests that compared to the smaller thrift banks, some of the larger commercial banks might have a comparative advantage in lending to medium firms.

Kernel densities of distribution of banks' direct lending to MSMEs from 2005 to 2010 show clustering around the Magna Carta targets (Figure 8). The kernel density estimates, which are skewed to the right, suggest that bank financing to micro and small enterprises (for most banks) comprise only about $10 \%$ of the banks' loan portfolios. Compliance to the medium enterprise provision has higher density at a slightly lower ratio of compliance, reflecting the lower required lending to medium enterprises as a ratio of the banks' loan portfolio. Figures 9 and 10 show the kernel density estimates of the distribution of MSME loan allocations according to bank type, ownership, and across time.

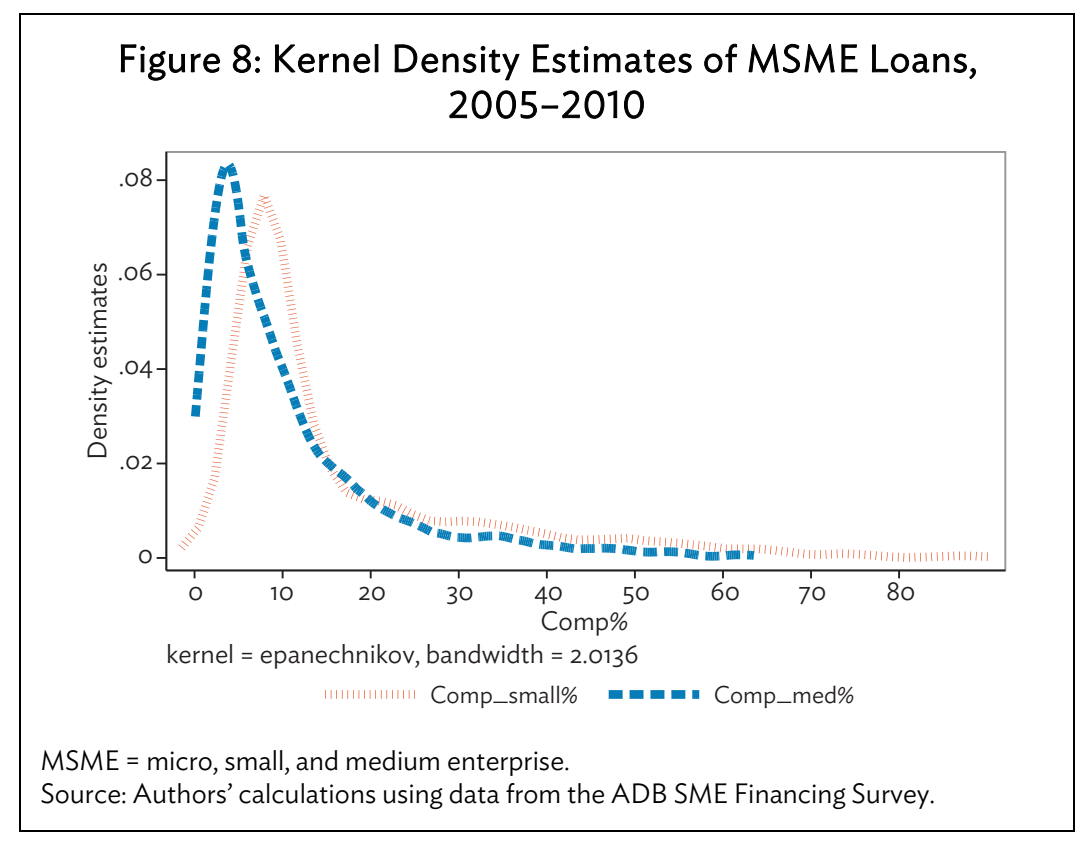

In support of our earlier findings, kernel density estimates suggest that more thrifts were focusing on lending to micro and small enterprises (Figure 9a). The distributions of the share of small firm financing to total loans of UKBs and foreign banks are concentrated to the left, with the density peaking at less than $10 \%$ of the banks' respective loan portfolios net of exclusions. Moreover, the kernel density estimates for the thrifts and domestic-owned banks revealed their bigger exposures to micro and small enterprises compared with UKBs and foreign banks. These initial findings are consistent with both existing empirical and theoretical literature, which predicts that larger banks and foreign-owned banks may be disadvantaged in lending to informationally opaque small businesses. 
Figure 9: Distribution of Loan Allocation to Micro and Small Enterprises, 2005-2010

a. UKBs versus THBs

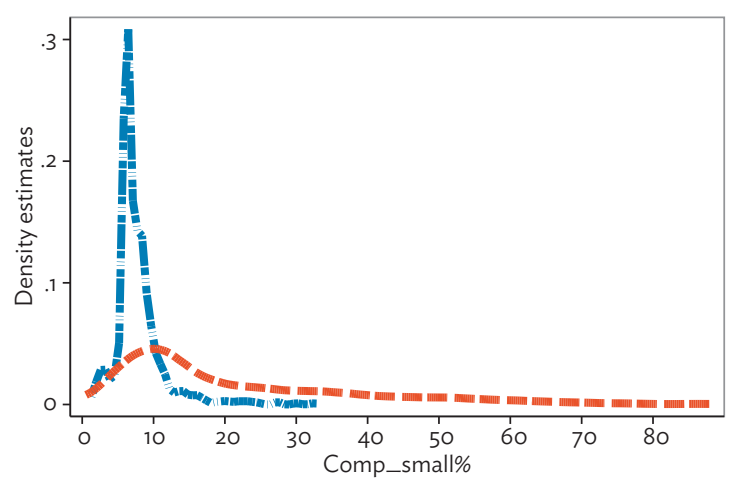

kernel $=$ epanechnikov, bandwidth $=0.4306$

|문 UKB 느 Thrift

b. UKBs through time

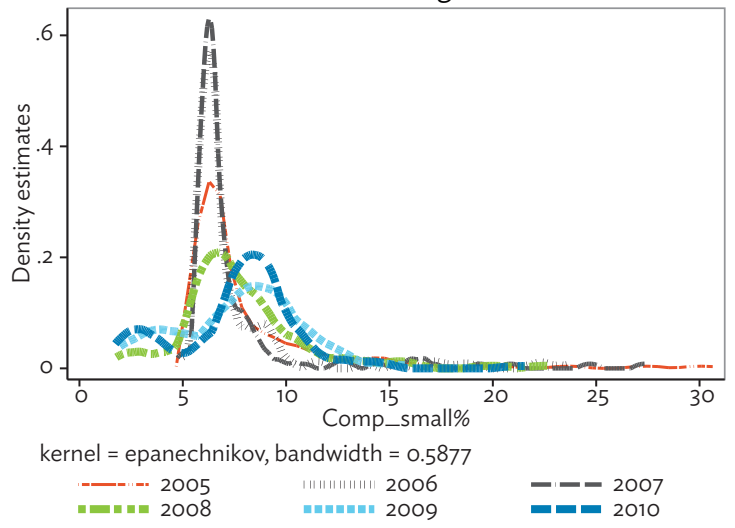

$\mathrm{THB}=$ thrift bank, $\mathrm{UKB}=$ universal and commercial bank

Source: Authors' calculations using data from the ADB SME Financing Survey.

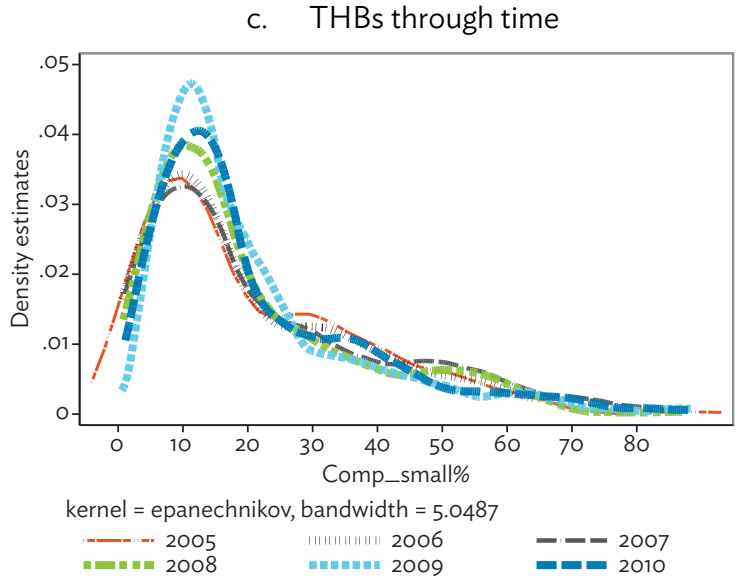

Nevertheless, UKBs increased their share of loans to smaller enterprises after 2009. Figures 10a.1 and 10b.2 show changes in the distribution of MSE lending of UKBs and foreign-owned banks through time. For the UKBs, we observe a modest shift to the right, suggesting that more banks comply within the 8\%-15\% range from 2009 compared with the earlier periods. Interestingly, it is around this period that the proposed amendment to the Magna Carta (i.e., increasing the legal target from $6 \%$ to $8 \%$ ) was fully implemented. Similar shifts are observed in the case of foreign bank MSE lending after 2008 with the tail extending further to the right, which may suggest increased lending to MSEs by foreign banks. The data also reveals a modest increase in the density estimate around compliance rates between $8 \%$ and $20 \%$ from 2008 along with a slight decrease between the $30 \%-60 \%$ range in the case of thrifts.

Figure 10, which shows banks' lending to medium enterprises, suggest a slightly different story particularly in the case of UKBs. Although the required lending to MEs is only set to $2 \%$, the median share of actual loans to medium enterprises are actually much higher than legally targeted. This is in contrast with UKBs' MSE lending, where most banks' lending clustered near 10\%, close to the imposed minimum mandatory credit allocation of $6 \%$ (from 2005-2007) and $8 \%$ (from 2008-2010). Figure 10a.1 also shows modest improvement in UKBs' ME financing starting in 2008 (the distribution is less 
skewed). On the other hand, the distribution of medium enterprise lending for thrifts and domestic banks' became more concentrated and more skewed to the right beginning 2008.

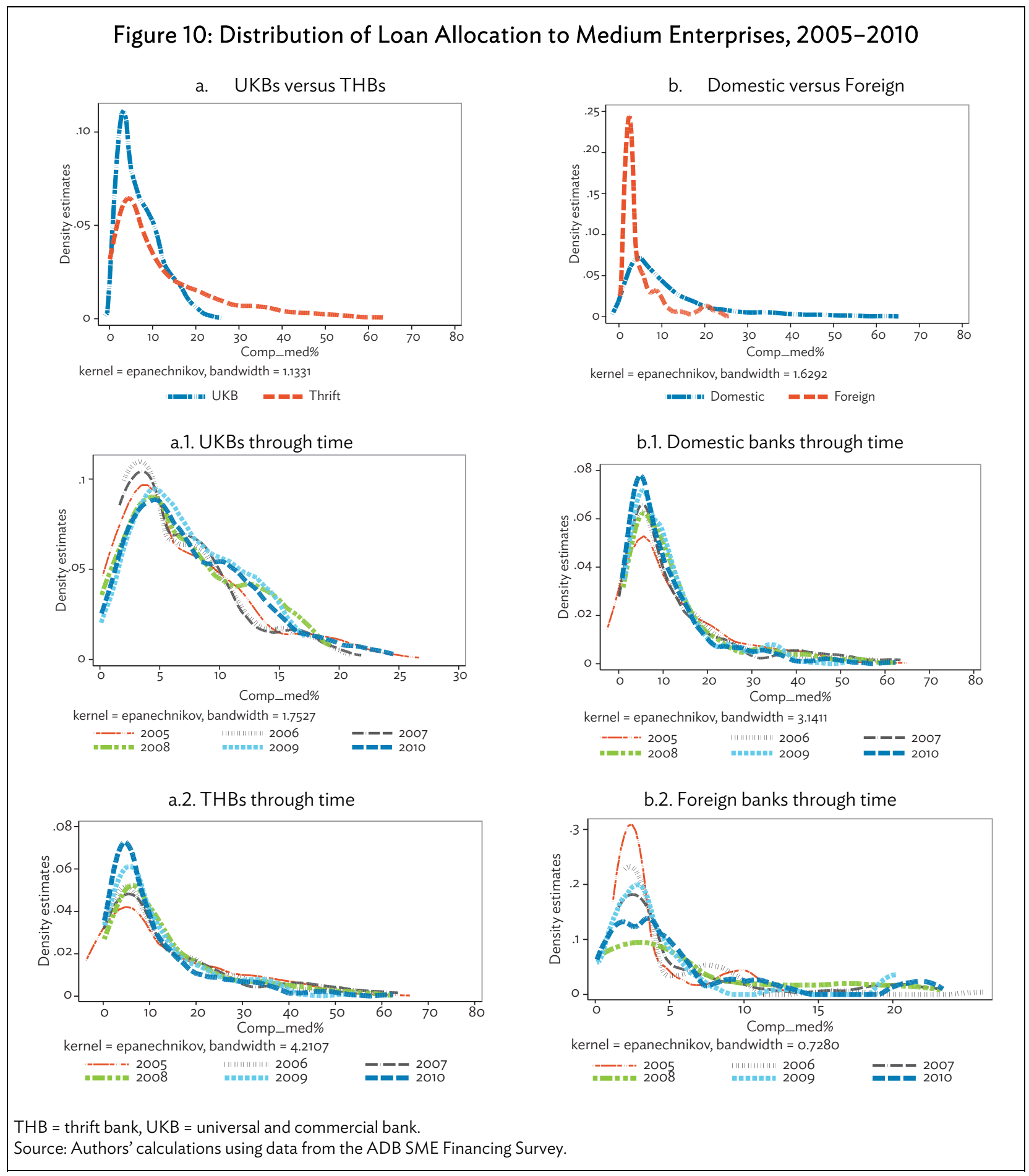




\section{Domestic and foreign banks within and outside of NCR}

Perhaps not surprisingly, banks headquartered in the Manila metropolitan area lent less to MSMEs relative to their counterparts headquartered elsewhere (Figure 11). The median MSME loan share by bank type, ownership, and location indicate that median portfolio share of micro and small firms for nonManila banks were consistently more than double that of lending institutions headquartered in the NCR. Furthermore, the median values of MSE financing are concentrated somewhere around the legal targets particularly for UKBs and foreign banks, and that the shift may just be an indication of the increase in the required lending from $6 \%$ to $8 \%$ in 2008 . We also observe an interesting development in loan to medium enterprises. In the earlier years, thrifts, domestic banks and banks headquartered outside the National Capital Region reported higher median share of medium enterprise loans. Nonetheless, this median share has been generally decreasing. By 2009, the median share of Manila-based banks actually surpassed that of non-Manila based banks. Further, by 2010, the median share of medium enterprises in the loan portfolio of UKBs was larger than that for thrifts. This suggests that new technology and the inclusion of microenterprises under the Magna Carta have changed the equilibrium and comparative advantages of various lending institutions and their target markets.

The six parts of Figure 12 further illustrate the range of distribution of the loan share of small firms across banks of different types, ownership, and geographic region over the period of study. From 2005 to 2007, at least 75\% of the UKBs directly complying with the Magna Carta lending targets for micro and small enterprises, when the legal target was set at $6 \%$ (Figure 12 a.1). However, the percentage of UKBs that complied diminished from 2008. By 2010, we see though that the 25th percentile value of micro and small enterprise loans returned to the same level as in 2005. Nevertheless, this is around 6\% or 2 percentage points shy from the required small firm financing after the Magna Carta was revised in 2008. Only around $50 \%$ of the UKBs in the sample are able to comply by 2010.

On the other hand, at least $75 \%$ of thrifts in 2008 (and beyond) complied with the mandated credit allocation of $8 \%$ to small enterprises. In fact, $50 \%$ of thrifts allotted almost $15 \%$ of their loans to micro and small firms, despite the very slight downward trend in the median share after 2008. Furthermore, a quarter of the thrifts allotted at least 30\% of their loans to micro and small firms (despite the dip in 2009). Most importantly, the 25th percentile loan share steadily increased from 2005 to 2010 for thrifts

For domestic banks as a whole (including UKBs and thrifts), we see modest increases in the 25th and 50th percentile values of loans to micro and small enterprises. We, however, observe that after 2007, the 75th percentile value declined. This suggests a decrease in the dispersion of optimal strategies and allocation of loans to micro and small enterprises.

Interestingly, the scenario observed in domestic banks is opposite to what is implied by the data of foreign banks, which saw a huge increase in dispersion in their optimal allocation of loans to smaller firms (Figure 12 b.2). Beginning in 2007, we observe a decrease in the 25th percentile lending share to smaller firms below the Magna Carta targets, accompanied by an increasing trend of foreign banks' median and 75th percentile loan shares. As a result, the dispersion of optimal strategies for foreign banks increased considerably, and the 75th/25th percentile ratio increased significantly from 2005 to 2010. 


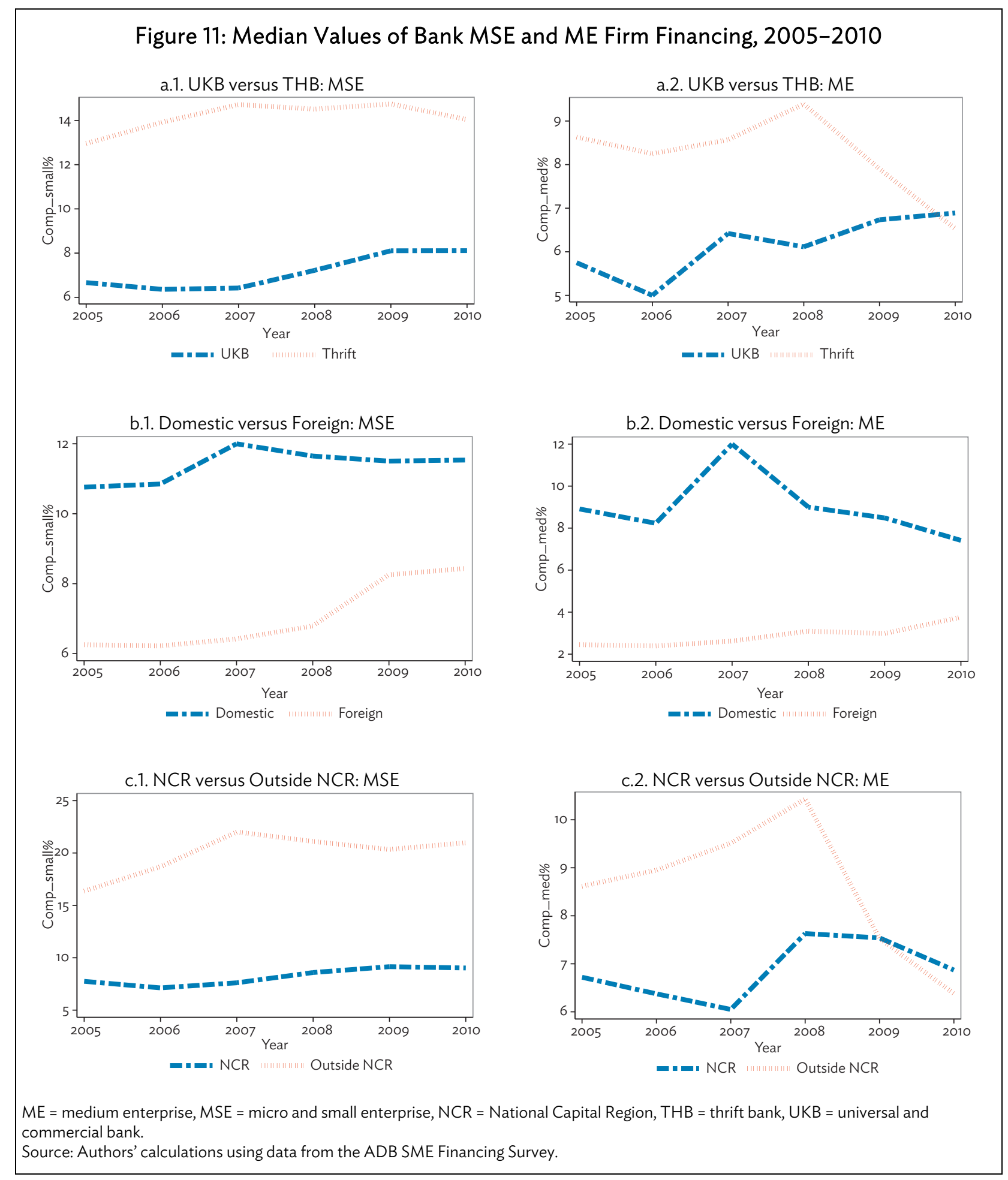


Figure 12: Percentile Values of Loans to Micro and Small Enterprises, 2005-2010

a.1. UKBs

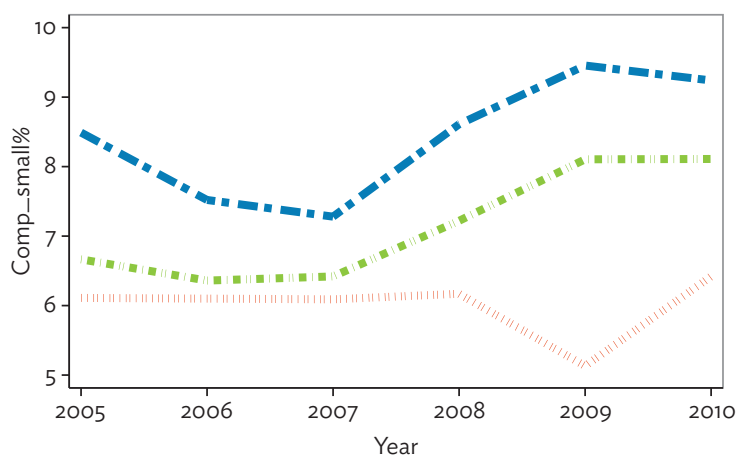

b.1. Domestic

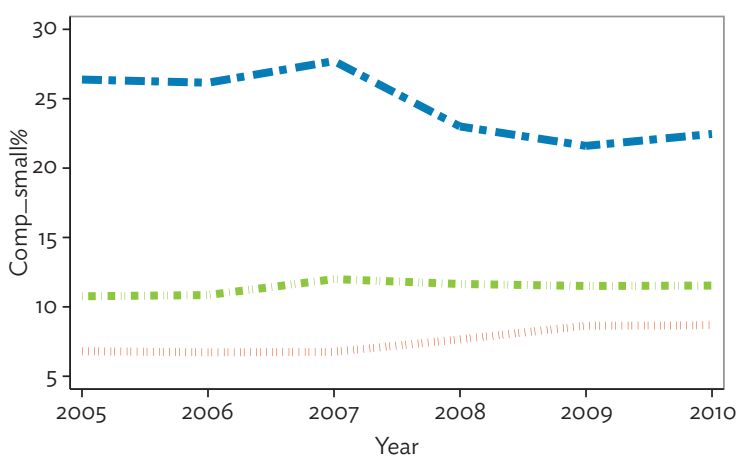

c.1. NCR

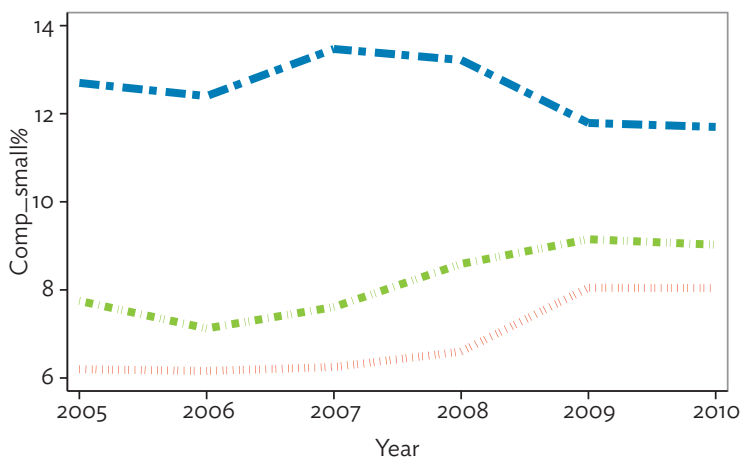

a.2. THBs

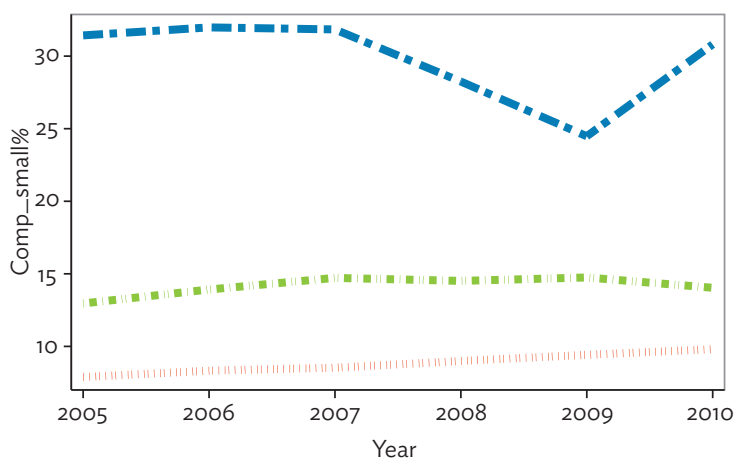

b.2. Foreign

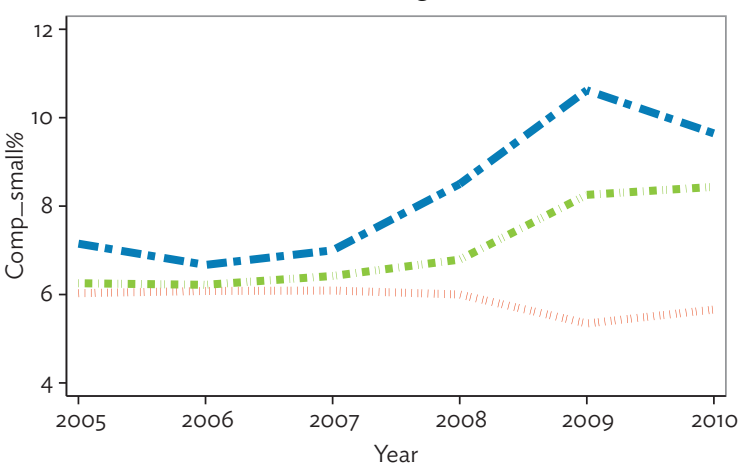

c.2. Outside NCR

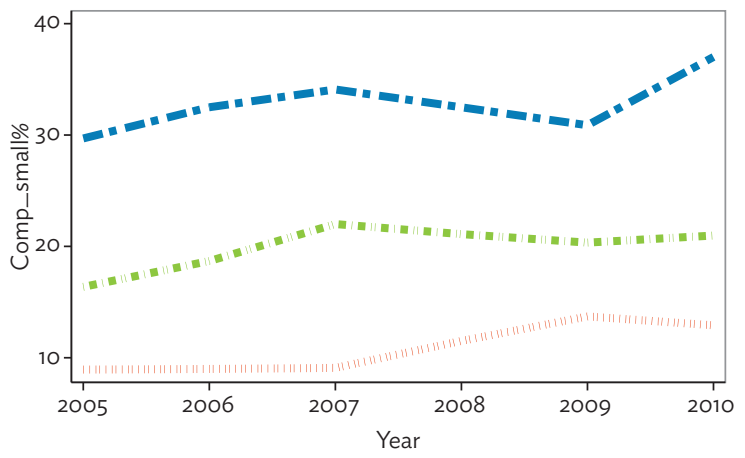

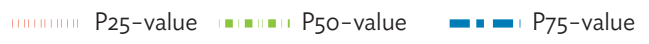

$\mathrm{NCR}=$ National Capital Region, $\mathrm{THB}=$ thrift bank, UKB $=$ universal and commercial bank. Source: Authors' calculations using data from the ADB SME Financing Survey.

Compliance, however, is another story. In the beginning of our study period, 2005 , at least $75 \%$ of the foreign banks complied with the Magna Carta target of $6 \%$ for smaller firms. By the end of the study period, a smaller proportion of the foreign banks complied directly with the legal target at $8 \%$ mandated in 2008. In a way, this suggests that the increase in the mandatory allocation to small firms may be less binding for foreign banks. As substantiated by empirical literature, foreign banks have numerous disadvantages relative to domestic banks when it comes to lending to small firms 
(e.g., personal ties, organizational structure, understanding of social dynamics, etc). In the case of the Philippines, these disadvantage could have been further limited branches and affiliates of foreign banks. Nevertheless, the data also indicated an increasingly divergent set of optimal strategies and a sorting of foreign banks into those that figured out how to lend to smaller firms profitably, against those that could not.

On the other hand, although non-Manila based banks tend to lend more to smaller firms, the location of banks headquarters did not matter as much in terms of general compliance for those at the 25th percentile. For both groups the 25th percentile value increased in 2009. However, for Manila-based banks the increase was just about enough to meet the new Magna Carta target, while for non-Manila based banks, the increase was significantly above the target. This is perhaps not surprising, given that the median non-Manila bank allocate over 20\% of their loans to smaller enterprises, well above $250 \%$ of the legal threshold. However, what is more interesting is the differences in the 75th/25th percentile ratio: for Manila banks, the 2008 amendment resulted in a narrowed dispersion of loan shares, while for non-Manila-based banks, the 75th percentile value increased sharply to above $35 \%$, thereby widening the dispersion of the loan allocation to smaller firms. Thus, it could be that the inclusion of microenterprises in the coverage of the Law has increased the direct compliance rates for non-Manila banks. By 2010, at least, 75\% of these banks allot at least approximately $13 \%$ of their portfolio to micro and small enterprises.

As we repeatedly saw, banks found it easier to comply with the Magna Carta targets for loans to medium enterprises. Across the six groupings we examined, all had 25th percentile lending rate that was above the legal target (Figure 13). We highlight two trends. First, the median lending of UKBs and foreign banks increased over time in contrast to thrifts and non-Manila-based banks where median lending decreased. By the end of 2010 , at least $75 \%$ of the UKBs allot at least $4 \%$ of their total loan portfolio to medium firms - more than double the Magna Carta minimum allocation of $2 \%$. In addition, about $50 \%$ of foreign banks allotted two times the required $2 \%$ mandatory credit allocation. Banks headquartered in the NCR, on the other hand, have more or less stable credit allocation to medium firms throughout the study period. The second point is that increasingly, there was a widening dispersion of optimal allocation of loans to medium firms by UKBs, while the dispersion decreased for every other group.

To further analyze the path dependence of optimal portfolio allocation for bank financing in the Philippines, we group the banks according to their financing behavior from 2005-2007. We define the following variables: StartLow, StartModerate, StartHigh, and StartVeryHigh. StartLow are the banks whose average compliance to the Magna Carta from 2005-2007, separately, are below the 25th percentile. StartModerate and StartHigh comprise the banks whose average lending from 2005-2007 are higher than the 25th percentile, but less than the median value and above the median but less than the 75th percentile, respectively. Finally, StartVeryHigh consists of banks whose average lending behavior of these banks through time. We highlight two significant changes after 2007 that may potentially affect small businesses financing: (i) the increased mandatory lending allocation to micro and small enterprises in 2008 and (ii) the global financial crisis from 2008-2009.

We note three important observations from Figure 14 depicting the median values of bank small firm financing through time according to bank type, ownership, and geographic region. First, for banks that started low and moderate (StartLow and StartModerate), their median values are stable (slight increases, but not notable) from 2005-2010, with the exception of foreign banks and banks headquartered outside the NCR. Second, for banks that allotted a significant proportion of their loan portfolio to smaller firms from 2005-2007, we see a significant decrease in the median lending share after 2007 for these group of banks regardless of the bank type, ownership, and geographic region. 
Third, we observe an increasing small firm financing trend for the foreign banks and Outside NCR for both StartLow and StartModerate.

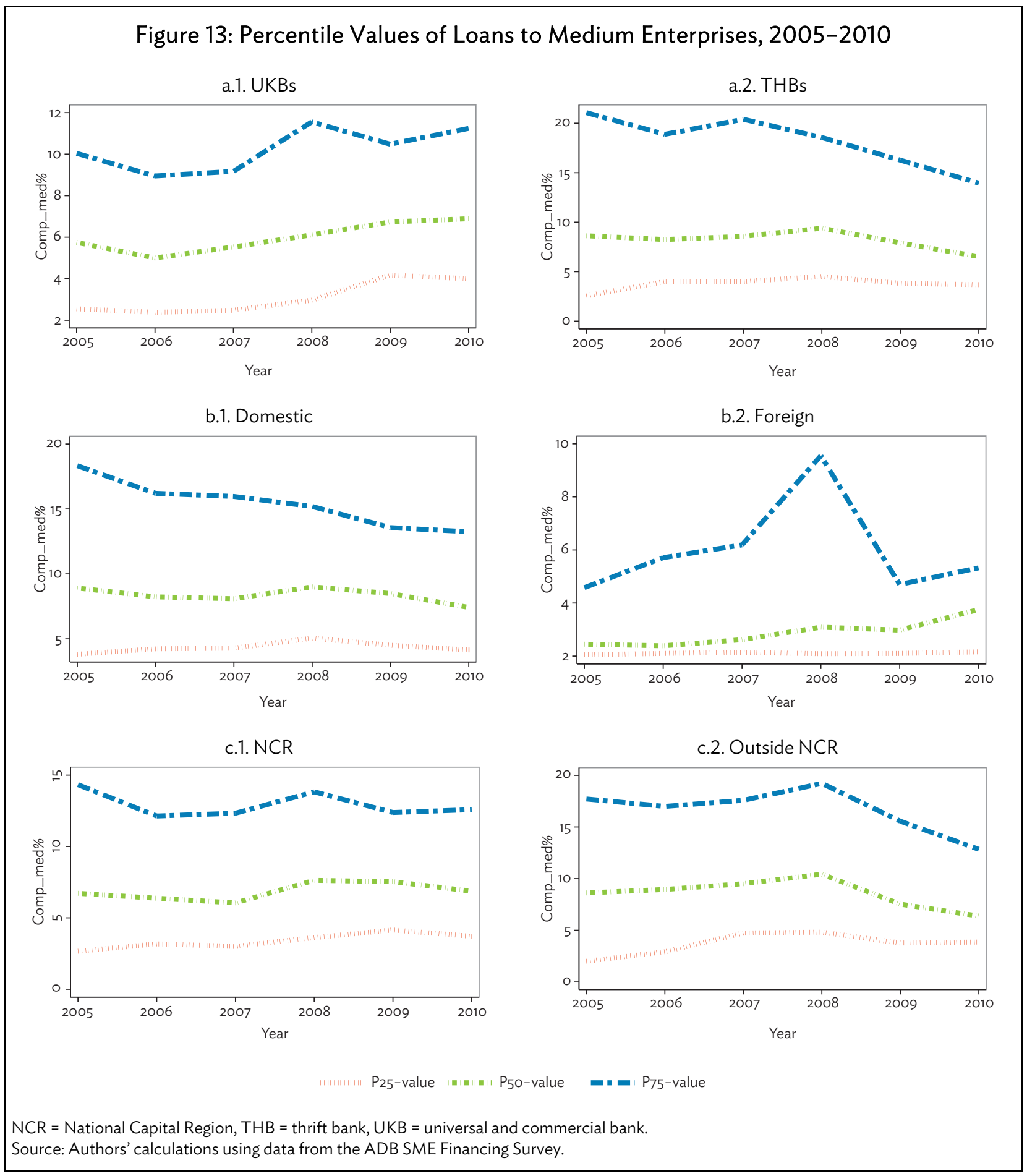




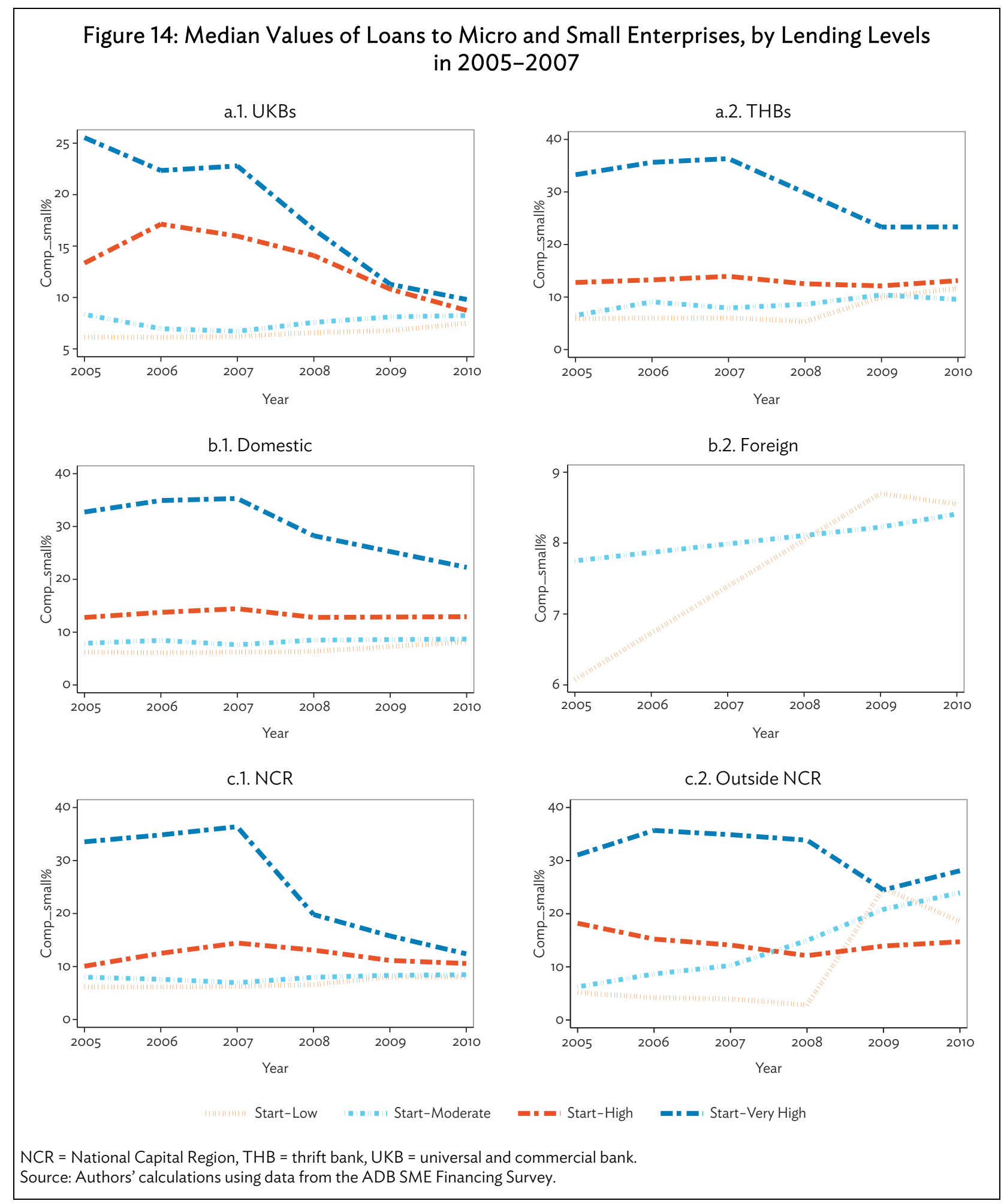

Similar to the convergence in lending to smaller firms, banks that allocate a significant proportion of their loan portfolio in financing medium-sized firms notably decreased their lending from 2007 (Figure 15). The median values between 2005 and 2010 are estimated to decrease by 10\% of the total loan portfolio (with the exception of banks headquartered outside NCR where the decrease is 
about 5\%). In contrast to smaller firms financing, we observe foreign banks' allocation of loans to medium firms has been decreasing throughout the period of study, notably those that are categorized under StartLow and StartModerate.

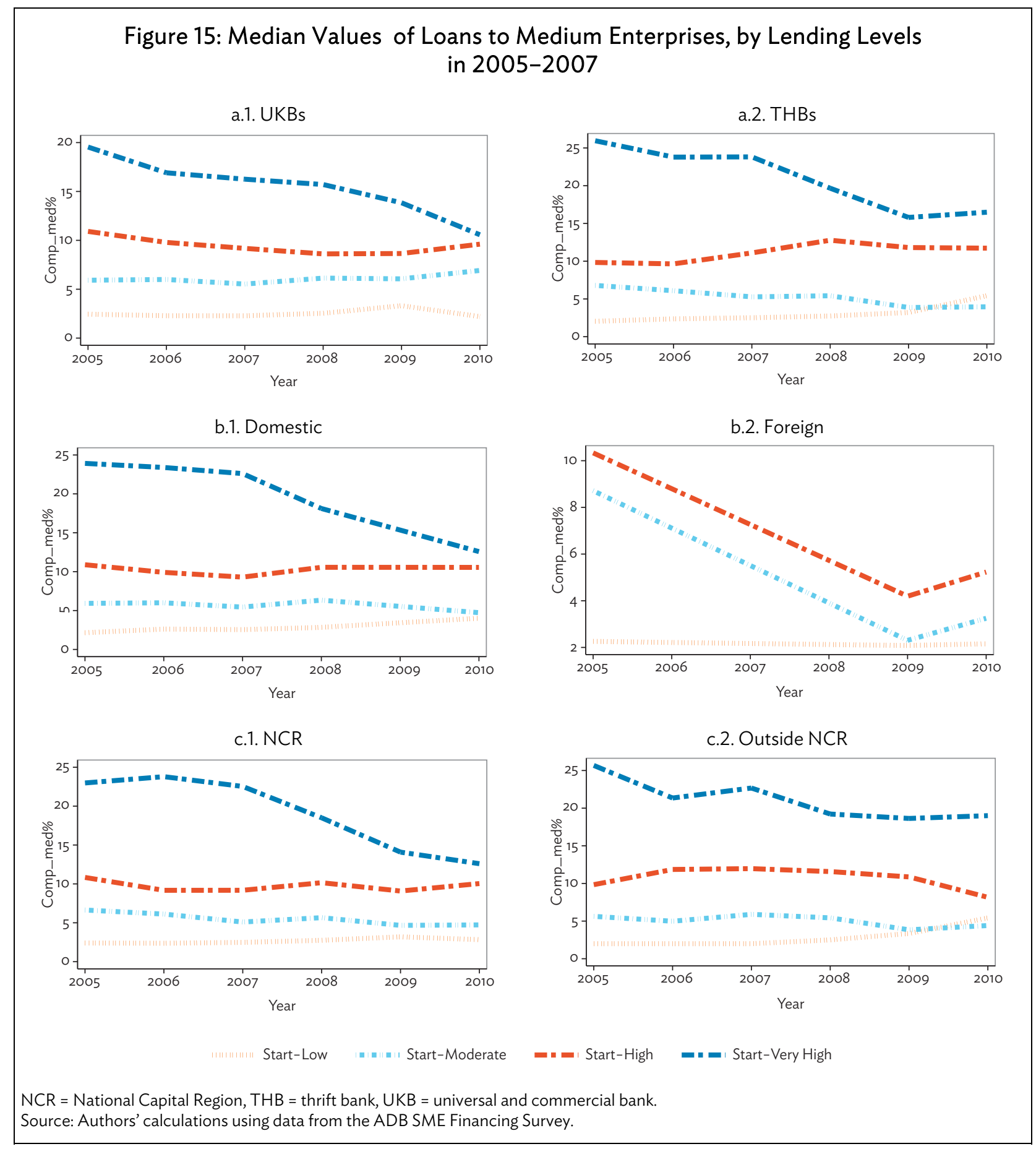




\section{RECENT DEVELOPMENTS AND POLICY IMPLICATIONS}

To summarize, our results highlighted three trends. First, although the total lending levels to MSMEs remained fairly stable, the percentage shares of loans allocated to MSMEs declined drastically from about $30 \%$ of total loans in 2002 to $16 \%$ of total loans in 2010 . Second, banks are finding it harder to meet the target for loans to smaller firms, especially after the target was revised upwards in 2008 . The new mandates resulted in a sharp increase in noncompliance in direct lending to micro and small firms, especially amongst universal and commercial banks. Kernel density estimates suggest that the revision of the Magna Carta in 2008 was binding for small firm lending particularly for the universal and commercial banks. Third, there is an increased dispersion in optimal loan portfolio across banks. Most surprisingly, the absolute level of MSME lending by rural co-ops declined since 2008.

Looking ahead, we see various developments recently could potentially further reduce banks' lending to MSMEs. For one, the implementation of the new Basel 3 framework, which raises banks' minimum financial ratios (e.g., Common Equity Tier 1 ratio, Tier 1 ratio and capital adequacy ratio), introduces new parameters such as liquidity coverage ratio and net stable funding ratio, and at the same time increases the risk weights of several asset items, could potentially siphon credit away from the MSME sector. These include the implementation of the Basel 3 parameters, the relaxation of foreign investor participation in rural co-ops, the establishment of the long-awaited credit information bureau, and the expansion of the Credit Surety Fund program of the BSP. There appears to a consensus that the new set of Basel 3 bank soundness criteria will have a dampening effect on MSME lending, not to mention that the BSP just announced a much higher set of ratios than what were prescribed by Basel 3. On the positive side, the latter three developments will most likely boost MSMEs' bankability.

Nonetheless, the BSP shows not only its willingness to adhere to the new set of standards but directed Philippine banks to maintain financial ratios that are 1.5 to 2 percentage points higher than the international benchmarks (BSP Circular No. 781 of 2013). It stipulated that inclusive of conservation buffer of $2.5 \%$ of risk-weighted assets, banks should maintain a Common Equity Tier 1 ratio of $8.5 \%$ (versus $7 \%$ in the $\mathrm{B} 3 \mathrm{~F}$ ), a Tier 1 ratio of $10 \%$ (versus $8.5 \%$ in the $\mathrm{B} 3 \mathrm{~F}$ ) and a capital adequacy ratio of $12 \%$ (versus $10 \%$ in the B3F). In the same circular it was noted that the new set of guidelines will be effective beginning 1 January 2014. ${ }^{33}$

Another potential drag on MSME financing is the continued decline in the number of rural coops (See box). A spate of bank closures has reduced the number of rural co-ops from 617 by end 2011 to 577 by the end of June 2013. This trend may not have a severe impact on the total value of loans by virtue of the small size of rural co-ops relative to the entire banking sector. But, adverse effect could be felt in terms of the number of MSME clients in the countryside that could lose access to formal credit and better served by rural co-ops prioritizing micro and small clients.

On the upside, recognizing the challenges faced by rural banks, the government passed RA 10574 on 24 May 2013 that effectively increased the allowable equity share of foreigners in rural banks from $40 \%$ to $60 \%$. The new law, which amended Sections 4 to 8 of the Rural Bank Act of 1992

33 OECD (2012) argued that "the retail risk rating (75\%) can be used to weight SME loans, provided the bank's portfolio is diverse and the bank's loan to an SME borrower is less than EUR1 million." Nevertheless, it also noted that "the weighting system also favors many large enterprises over small ones: large companies with good external credit ratings (AAA) are assigned a $20 \%$ risk weight, whereas SMEs that are unrated have risk weightings of $100 \%$ or $75 \%$. Under Basel III, the difference in core Tier 1 capital the bank needs to hold against their loans is remarkable: $7 \%$ of the loan for SMEs with $100 \%$ risk weighting, as opposed to $1.4 \%(7 \% \times 20 \%)$ for a large company with an AAA rating." 
(RA 7353), sought to assist rural banks in meeting the capital requirements and put them "on a level playing field with its thrift and commercial banking counterparts that are able to take in foreign partners" according to one of the bill's authors in the Senate (Macrohon 2013).

The prospect of having a fully functional credit information bureau by end of 2014 could also help a lot in improving the transparency of MSMEs' financial standing. Named Credit Information Corporation ( $\mathrm{CiC}$ ), the government-owned and controlled credit bureau was established courtesy of the passage of the Credit Information System Act (RA 9510) on 31 October 2008. The implementing rules and regulations of RA 9510 were ironed out on 27 May 2009. However, it took more than 2 years before $\mathrm{CiC}$ started operating on 16 December 2011 and another 5 months before its board members were appointed by the President. ${ }^{34}$ Recently, the Securities and Exchange Commission, which is the government agency taking charge in setting up $\mathrm{CiC}$, announced that it is expecting the new credit bureau to function fully in December 2014 (Dumlao 2013).

The $\mathrm{CiC}$, which will mainly target small businesses, is a public-private partnership co-owned by the government (60\%) and the private sector (40\%). As of November 2012, the private sector parties with stakes in the corporation include the Philippine Cooperatives Center, Bankers Association of the Philippines (BAP), Credit Card Association of the Philippines, Chamber of Thrift Banks, Rural Bankers Association of the Philippines, and the Philippine Credit Reporting Alliance (CiC 2012). Note that, prior to the establishment of $\mathrm{CiC}$, two credit bureaus have been created. These are the Credit Information Bureau Inc., which was an initiative of the Central Bank of the Philippines and the Financial Executives Institute of the Philippines, and the BAP Credit Bureau set up by the BAP in 1991. ${ }^{35}$ However, the aforementioned two credit bureaus have largely confined their operations within large companies.

The expansion of the BSP's Credit Surety Fund program is an additional booster to MSME lending. From just one fund, the number of pooled resource financing vehicle rose to 27 by the end of March 2013. Since 2010, the approved loans increased fivefold from P134 million to P679.2 million by the end of the first quarter of 2013. In the same period, released loans increased over sixfold from a little less than P82.2 million to P501.6 million. ${ }^{36}$

\section{CONCLUSION}

Despite the Magna Carta and its subsequent revisions along with the accompanying support measures, bank lending to MSMEs has not increased much. More disconcertingly, MSME lending is generally on a decline as a ratio of banks' total loan portfolio. A substantial drop in MSMEs' share in bank loans is particularly evident among UKBs. Even thrifts and rural co-ops, which are supposed to be the ones absorbing the MSME credit demand, have likewise reduced their lending ratios to the MSMEs quite significantly from 2004 to 2010 . Although nominal values show that lending by thrifts and rural co-ops to MSMEs are growing at a decent pace, it appears that their lending to other sectors are expanding even more briskly.

Smaller firms are impacted more than medium-sized firms with the ongoing migration of bank lending portfolio to non-MSME clients. UKBs as a group have already decreased their MSME lending

34 See CiC Milestones: Historical Background and Timeline.

35 The Central Bank of the Philippines was renamed Bangko Sentral ng Pilipinas in 1993 (See box).

36 See BSP (2013b). 
below the mandated $8 \%$ ratio. At the level of individual institutions, there is also a notable increase in the number of UKBs not complying with the MSE lending provision of the Magna Carta. In other words, it is more profitable for UKBs to pay the penalties rather than lend to MSEs.

On the other hand, MSE lending of thrifts and RCBs continues to expand. But, lending data illustrate that the share of MSEs in their credit disbursements has declined significantly although still well above the Magna Carta's required ratio. Further research would be required to understand the determinants of this pattern. Nonetheless, understanding these recent changes in MSME lending preferences would be essential in crafting future financial inclusion programs. On a positive note, bank-level data suggest that more thrifts have recently become more compliant to MSE lending requirement.

We conjecture that perhaps abolishing the Magna Carta targets for loans to medium-sized enterprises might not have much adverse effects. It is also notable that consistently, banks do not have trouble complying with the mandated lending ratio for middle-sized firms. As of 2010, UKBs, thrifts and rural co-ops maintained a good positive margin with respect to the legal requirement and noncompliance was limited. However, the steady downward trend in MSME loan allocation across bank groups in recent years cannot be overlooked. This trend parallels the downward drift of banks' lending ratio to micro and small firms explained above. The differences lie in the degree of the decline - which is more muted in the case of lending to medium firms whereby the banks' allocation was still much higher than mandated by law.

The overall pattern of decreasing share of bank lending to MSMEs thus suggests a need to revisit, if not redesign, the current MSME lending policy framework. While the dynamism of the MSME sector hinges upon having reliable access to financing, banks in return should be given reasonable incentives to align their business models with the government's social agenda. In addition, there are ways to increase alternative sources of credit for MSMEs, such as developing equities and bonds market suitable for MSMEs. The government could also further improve measures to increase financing supply by harnessing untapped domestic savings and foreign exchange reserves rather than relying on a strict mandate on banks' portfolio allocation. Banks were finding it increasingly onerous to comply with the law and more than a half of commercial and universal banks undercomplied for at least a quarter during the period we observed. Expanding alternative means of financial access for MSMEs would be even more important given looming policy and institutional changes. 


\section{APPENDIX}

Table A.1: Bank-Level Data for Universal and Commercial Banks

\begin{tabular}{|c|c|c|c|c|c|c|c|c|}
\hline \multirow[b]{2}{*}{ Quarter } & \multicolumn{4}{|c|}{ Data on Loans to Micro and Small Enterprises } & \multicolumn{4}{|c|}{ Data on Loans to Medium Enterprises } \\
\hline & $\begin{array}{c}\text { Total } \\
\text { Number } \\
\text { of Banks }\end{array}$ & $\begin{array}{c}\text { Total } \\
\text { Number } \\
\text { of Banks } \\
\text { with Data }\end{array}$ & $\begin{array}{c}\text { Number of } \\
\text { Compliant } \\
\text { Banks }\end{array}$ & $\begin{array}{c}\text { Number of } \\
\text { Noncompliant } \\
\text { Banks }\end{array}$ & $\begin{array}{c}\text { Total } \\
\text { Number } \\
\text { of Banks }\end{array}$ & $\begin{array}{c}\text { Total } \\
\text { Number } \\
\text { of Banks } \\
\text { with Data }\end{array}$ & $\begin{array}{c}\text { Number of } \\
\text { Compliant } \\
\text { Banks }\end{array}$ & $\begin{array}{c}\text { Number of } \\
\text { Noncompliant } \\
\text { Banks }\end{array}$ \\
\hline Q12005 & 42 & 40 & 40 & 0 & 42 & 40 & 40 & 0 \\
\hline Q2 2005 & 42 & 40 & 38 & 2 & 42 & 39 & 39 & 0 \\
\hline Q3 2005 & 41 & 39 & 39 & 0 & 41 & 39 & 39 & 0 \\
\hline Q4 2005 & 41 & 39 & 38 & 1 & 41 & 39 & 38 & 1 \\
\hline Q12006 & 41 & 40 & 39 & 1 & 41 & 40 & 40 & 0 \\
\hline Q2 2006 & 40 & 39 & 39 & 0 & 40 & 39 & 39 & 0 \\
\hline Q3 2006 & 40 & 38 & 36 & 2 & 40 & 38 & 38 & 0 \\
\hline Q4 2006 & 40 & 38 & 36 & 2 & 40 & 38 & 38 & 0 \\
\hline Q1 2007 & 40 & 38 & 36 & 2 & 40 & 38 & 36 & 2 \\
\hline Q2 2007 & 39 & 37 & 37 & 0 & 39 & 37 & 37 & 0 \\
\hline Q3 2007 & 39 & 32 & 31 & 1 & 39 & 32 & 31 & 1 \\
\hline Q4 2007 & 39 & 31 & 28 & 3 & 39 & 30 & 30 & 0 \\
\hline Q1 2008 & 39 & 30 & 26 & 4 & 39 & 30 & 30 & 0 \\
\hline Q2 2008 & 39 & 30 & 27 & 3 & 39 & 30 & 29 & 1 \\
\hline Q3 2008 & 39 & 29 & 23 & 6 & 39 & 28 & 27 & 1 \\
\hline Q4 2008 & 39 & 29 & 17 & 12 & 39 & 27 & 24 & 3 \\
\hline Q1 2009 & 39 & 30 & 16 & 14 & 39 & 28 & 25 & 3 \\
\hline Q2 2009 & 39 & 27 & 16 & 11 & 39 & 27 & 25 & 2 \\
\hline Q3 2009 & 39 & 27 & 16 & 11 & 39 & 28 & 26 & 2 \\
\hline Q4 2009 & 39 & 26 & 16 & 10 & 39 & 28 & 25 & 3 \\
\hline Q1 2010 & 39 & 26 & 16 & 10 & 39 & 28 & 26 & 2 \\
\hline Q2 2010 & 39 & 27 & 17 & 10 & 39 & 28 & 26 & 2 \\
\hline Q3 2010 & 40 & 28 & 15 & 13 & 40 & 29 & 27 & 2 \\
\hline Q4 2010 & 39 & 27 & 18 & 9 & 39 & 30 & 27 & 3 \\
\hline Q1 2011 & 39 & 27 & 15 & 12 & 39 & 30 & 26 & 4 \\
\hline Q2 2011 & 39 & 29 & 16 & 13 & 39 & 31 & 27 & 4 \\
\hline
\end{tabular}

Source: Authors' calculations using the data from the Bangko Sentral ng Pilipinas. 
Table A.2: Bank-Level Data for Thrifts

\begin{tabular}{|c|c|c|c|c|c|c|c|c|}
\hline & \multicolumn{4}{|c|}{ Data on Loans to Micro and Small Enterprises } & \multicolumn{4}{|c|}{ Data on Loans to Medium Enterprises } \\
\hline Quarter & $\begin{array}{c}\text { Total } \\
\text { Number } \\
\text { of Banks }\end{array}$ & $\begin{array}{c}\text { Total } \\
\text { Number } \\
\text { of Banks } \\
\text { with } \\
\text { Data }\end{array}$ & $\begin{array}{c}\text { Total } \\
\text { Number of } \\
\text { Banks }\end{array}$ & $\begin{array}{c}\text { Total } \\
\text { Number } \\
\text { of Banks } \\
\text { with Data }\end{array}$ & $\begin{array}{c}\text { Total } \\
\text { Number } \\
\text { of Banks }\end{array}$ & $\begin{array}{c}\text { Total } \\
\text { Number } \\
\text { of Banks } \\
\text { with } \\
\text { Data }\end{array}$ & $\begin{array}{c}\text { Total } \\
\text { Number of } \\
\text { Banks }\end{array}$ & $\begin{array}{c}\text { Total } \\
\text { Number } \\
\text { of Banks } \\
\text { with Data }\end{array}$ \\
\hline Q12005 & 85 & 64 & 55 & 9 & 85 & 60 & 55 & 5 \\
\hline Q2 2005 & 85 & 63 & 58 & 5 & 85 & 59 & 53 & 6 \\
\hline Q3 2005 & 84 & 63 & 58 & 5 & 84 & 60 & 55 & 5 \\
\hline Q4 2005 & 84 & 63 & 54 & 9 & 84 & 59 & 53 & 6 \\
\hline Q1 2006 & 86 & 63 & 57 & 6 & 86 & 59 & 56 & 3 \\
\hline Q2 2006 & 84 & 62 & 57 & 5 & 84 & 59 & 54 & 5 \\
\hline Q3 2006 & 84 & 62 & 56 & 6 & 84 & 61 & 56 & 5 \\
\hline Q4 2006 & 84 & 67 & 62 & 5 & 84 & 66 & 63 & 3 \\
\hline Q1 2007 & 85 & 66 & 63 & 3 & 85 & 66 & 64 & 2 \\
\hline Q2 2007 & 83 & 65 & 62 & 3 & 83 & 65 & 63 & 2 \\
\hline Q3 2007 & 83 & 65 & 59 & 6 & 83 & 64 & 62 & 2 \\
\hline Q4 2007 & 83 & 63 & 58 & 5 & 83 & 62 & 59 & 3 \\
\hline Q1 2008 & 82 & 65 & 58 & 7 & 82 & 64 & 61 & 3 \\
\hline Q2 2008 & 81 & 64 & 58 & 6 & 81 & 62 & 59 & 3 \\
\hline Q3 2008 & 81 & 62 & 57 & 5 & 81 & 60 & 58 & 2 \\
\hline Q4 2008 & 81 & 62 & 56 & 6 & 81 & 59 & 56 & 3 \\
\hline Q1 2009 & 76 & 65 & 60 & 5 & 76 & 63 & 60 & 3 \\
\hline Q2 2009 & 76 & 64 & 61 & 3 & 76 & 60 & 58 & 2 \\
\hline Q3 2009 & 75 & 64 & 60 & 4 & 75 & 62 & 61 & 1 \\
\hline Q4 2009 & 75 & 64 & 62 & 2 & 75 & 63 & 61 & 2 \\
\hline Q1 2010 & 75 & 63 & 61 & 2 & 75 & 62 & 60 & 2 \\
\hline Q2 2010 & 75 & 63 & 61 & 2 & 75 & 63 & 59 & 4 \\
\hline Q3 2010 & 74 & 64 & 63 & 1 & 74 & 62 & 59 & 3 \\
\hline Q4 2010 & 74 & 64 & 62 & 2 & 74 & 62 & 59 & 3 \\
\hline $\begin{array}{l}\text { Q1 } 2011 \\
\text { Q2 } 2011\end{array}$ & 74 & 63 & 61 & 2 & 74 & 62 & 59 & 3 \\
\hline
\end{tabular}

Source: Authors' calculations using the data from the Bangko Sentral ng Pilipinas. 


\section{BIBLIOGRAPHY}

Asian Development Bank (ADB). 2004. Technical Assistance to the Republic of the Philippines for Strengthening SME Credit Management Systems. Manila.

2005. Report and Recommendation of the President to the Board of Directors on Proposed loan, partial credit guarantee, and equity investment to the Republic of the Philippines for the Small and Medium Enterprise Development. Manila.

2010. Philippines: Small and Medium Enterprise Development Support Project. Completion Report.

Bangko Sentral ng Pilipinas (BSP). 1997. BSP Circular 147. Manila. 24 October.

1999. Circular Letter. Guidelines on the Suspension of the Grant of New Bank Licenses. Manila. 10 September.

2001a. BSP Circular 273. Manila. 27 February.

2001b. BSP Circular 277. Manila. 21 March.

2002. BSP Circular 363. Manila. 3 December.

2003. BSP Circular 364. Manila. 9 January.

2004. Status Report on BSP Initiatives to Improve Credit Access of Small and Medium Enterprises. BSP Media Release. 2 February.

2005. BSP Circular 505. Manila. 22 December.

2007. BSP Circular Letter 2007-039. Manila. 4 July.

2008a. BSP Circular 625. Manila. 14 October.

2008b. BSP Circular 632. Manila. 13 November.

_.2008c. Manual of Regulations for Banks. Manila. http://www.bsp.gov.ph/downloads/ regulations/morb.pdf

2010a. Status Report on the Philippine Financial System. 2nd Semester 2009. Manila

2010b. Status Report on the Philippine Financial System. 1st Semester 2010. Manila.

2011a. BSP Circular 728. Manila. 23 June.

2011b. BSP Circular 726. Manila. 27 June.

_.2011c. BSP Circular 736. Manila 20 July. 
2011d. BSP Circular 732. Manila. 3 August.

2011e. Manual of Regulations for Banks. Volume 1. Manila. December.

- 2012. Monetary Board Approves Rationalization of Reserve Requirement Policy. BSP Media Release. Manila. 2 March.

2013a. BSP Circular 781. Manila.

2013b. Credit Surety Fund: Sustaining Economic Growth through Increased Credit Flows. Accomplishments as of 31 March 2013. Presentation. CSF Rationale and Mechanics. Manila.

2013c. Credit Surety Fund Frequently Asked Questions. June. Manila.

—. Various issues. Report on Economic and Financial Developments. Manila.

Berger, A. N. and G. F. Udell. 2006. A More Conceptual Framework for SME Finance. Journal of Banking \& Finance. 30 (11). pp. 2945-66.

Clavesillas, J. 2013. Mobilizing Private Resources for Financing Inclusive Green Growth. Presentation. G20 Development Working Group Workshop on Inclusive Green Growth (OECD). Moscow. 7 July.

Credit Information Corporation (CiC). 2012. Credit Information Bureau to Help Rural Banks Further Boost Countryside Growth. http://creditinfo.gov.ph/news/credit-information-bureau-help -rural-banks-further-boost-countryside-growth

—. Milestones: Historical Background and Timeline. http://creditinfo.gov.ph/milestones

de la Torre, A., M. S. Martínez Pería, and S. L. Schmukler. 2010. Bank Involvement with SMEs: Beyond Relationship Lending. Journal of Banking \& Finance. 34 (2010). pp. 2280-93.

Dohner, R. and P. Intal, Jr. 1989. Debt Crisis and Adjustment. Developing Country Debt and Economic Performance, Volume 3. Chicago: University of Chicago Press.

Dumlao, D. 2013. Centralized Credit Bureau Seen to Open in Dec. '14. Philippine Daily Inquirer. 22 September. http://business.inquirer.net/144047/centralized-credit-bureau-seen-to-open -in-dec-14

Financial Executives Institute of the Philippines (FINEX) and Ateneo Center for Research and Development (ACERD). 2006. Making SMEs Work, Making SMEs Create Work: Job Creation Through Small and Medium Enterprise Development.

Gochoco-Bautista, M. S. 1999. The Past Performance of the Philippine Banking Sector and Challenges in the Postcrisis Period. Rising to the Challenge in Asia: A Study of Financial Markets. Volume 10 - Philippines. Asian Development Bank. Manila.

Government of the Republic of the Philippines. 1990. Republic Act (RA) 6848: The Charter of the AlAmanah Islamic Investment Bank of the Philippines. Manila. 26 January. 
—. 1991. RA 6977: Magna Carta for Small Enterprises. Manila. 24 January.

— 1992. RA 7353: The Rural Bank Act of 1992. Manila. 2 April.

_. 1997. RA 8289: Amending RA 6977. Manila. 6 May.

2000. RA 8791: The General Banking Law of 2000. Manila. 23 May.

2008. RA 9501: Magna Carta for Micro, Small and Medium Enterprises (MSMEs). Manila. 23 May.

2008. RA 9510: Credit Information System Act. Manila. 31 October.

—2010. RA 10000: The Agri-Agra Reform Credit Act of 2009. Manila. 23 February.

2013. RA 10574: Amending RA 7353 (The Rural Bank Act of 1992). Manila. 24 May.

Inter-American Development Bank (IADB). 2004. Unlocking Credit: The Quest for Deep and Stable Lending. Washington, DC: The Johns Hopkins University Press.

Khor, N., I. Sebastian, and R. Aldaba. 2013. Enterprises in the Philippines: Dynamism and Constraints to Employment Growth. ADB Economics Working Paper Series No. 334. Manila.

Lagua, B. 2011. Is the Magna Carta for SMEs Increasing the Sector's Access to Credit? Manila Bulletin. 10 March.

Lamberte, M. 2002. Financing for Micro-Enterprises, Small and Medium-Sized Business and Poor Households in the Philippines. Rejuvenating Bank Finance for Development in Asia and the Pacific. New York: UN Economic and Social Commission for Asia and the Pacific (UNESCAP) and Asian Development Bank (ADB).

Macrohon, P. S. 2013. Senate Allows Foreign Capital Infusion in Rural Banks. Senate of the Philippines $-16^{\text {th }}$ Congress. Public Relations and Information Bureau (PRIB). Press Release. 28 January. http://www.senate.gov.ph/press_release/2013/0128_prib4.asp

Manlagñit, M. C. and M. Lamberte. 2004. Evaluating the Impacts of Competition Policy Reforms on the Efficiency of Philippine Commercial Banks. PIDS Discussion Paper Series No. 2004-46. Manila.

Medalla, F. and J. N. Ravalo. 1997. The Impact of Mandated Credit Programs on Financial Institutions. Credit Policy Improvement Program, Department of Finance - National Credit Council. Manila.

Nangia, R. and L. Vaillancourt. 2007. Small and Medium Enterprise Financing in the Philippines: A Scoping Study - Finding the Gaps in Access to Financing for SMEs. Washington, DC: International Finance Corporation. 
Nascimento, J.-C. 1990. The Crisis in the Financial Sector and the Authorities' Reaction: The Case of the Philippines. IMF Working Paper No. WP/90/26. Washington, DC: International Monetary Fund.

Nasution, A. 1999. Recent Issues in the Management of Macroeconomic Policies in the Philippines. Rising to the Challenge in Asia: A Study of Financial Markets. Volume 10 - Philippines. Manila: Asian Development Bank.

Organisation for Economic Co-operation and Development (OECD). 2012. Financing SMEs and Entrepreneurs 2012: An OECD Scoreboard. Paris: Organisation for Economic Co-operation and Development Publishing.

Oum, S., C. Harvie, and D. Narjoko. 2010. SME Access to Finance in Selected East Asian Economies. SME Access to Finance in Selected East Asian Economies - Chapter 3. ERIA Research Project Report 2010, No. 14.

Pasadilla, G. and M. Milo. 2005. Effect of Liberalization on Banking Competition. PIDS Discussion Paper Series 2005-03. Manila.

Philippine Export-Import Credit Agency. About Us. http://www.philexim.gov.ph/index.php?option $=$ com $\_$content $\&$ view $=$ article $\& i d=20 \&$ Itemid $=102$

Singson, G. 1999. Towards a Sound Financial System: The Philippine Experience. Speech. The International Conference on Central Banking Policies. Macau, China. 14 May.

Small and Medium Enterprise Development (SMED). 2003. SMED Resolution No. 1. Manila. 16 January.

Small Business Corporation (SBC). 2011. SBC Information Memorandum Issue No. 6 - 2011. Manila.

—. History. http://www.sbgfc.org.ph/index.php/about-us/history

World Bank. 2009. World Bank Enterprise Surveys (WBES). Washington, DC. 


\section{Assessing Mandated Credit Programs: Case Study of the Magna Carta in the Philippines}

This paper examines the Magna Carta Law in the Philippines, which mandates banks to allocate $2 \%$ of their total loan portfolios to medium-sized firms and $8 \%$ to micro and small firms. The paper highlights three findings. First, although total lending to micro, small, and medium enterprises (MSMEs) grew slightly, MSME loan shares declined drastically from $30 \%$ in 2002 to $16.4 \%$ in 2010 . Second, there was a sharp rise in noncompliance after loan targets increased in 2008. Third, there is increased heterogeneity in optimal loan portfolio across banks. Most surprisingly, total MSME lending by rural and cooperative banks declined since 2008. Abolishing Magna Carta target for medium-sized enterprise loans would most likely yield little adverse effects.

\section{About the Asian Development Bank}

ADB's vision is an Asia and Pacific region free of poverty. Its mission is to help its developing member countries reduce poverty and improve the quality of life of their people. Despite the region's many successes, it remains home to the majority of the world's poor. $A D B$ is committed to reducing poverty through inclusive economic growth, environmentally sustainable growth, and regional integration.

Based in Manila, ADB is owned by 67 members, including 48 from the region. Its main instruments for helping its developing member countries are policy dialogue, loans, equity investments, guarantees, grants, and technical assistance. 